\title{
" ممارسة الأنشطة الترويحية و أثرها فى تقبل صورة الجسد "
}

\section{د. دفوث علي جمعه}

\section{* قدمة ومشكلة الدراسة:}

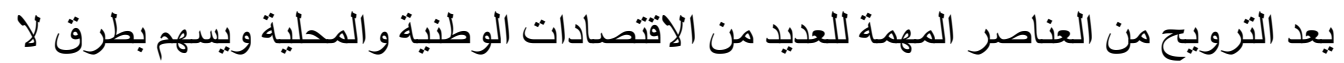

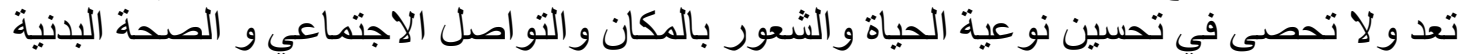
و النفسية و التعلم و غير ذللك من الأثياء غير المادية.

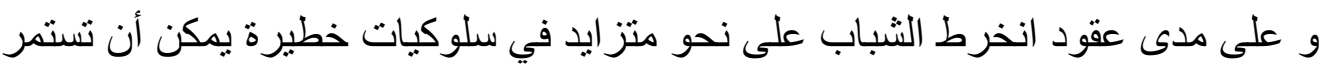

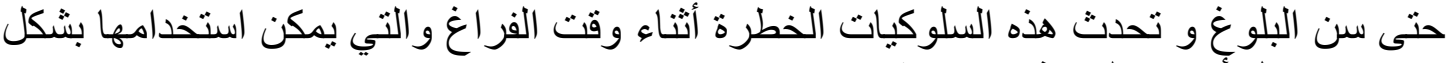
جيد من خلال أوقات الفر اغ الإنيجابية. ( 17 : 230 )

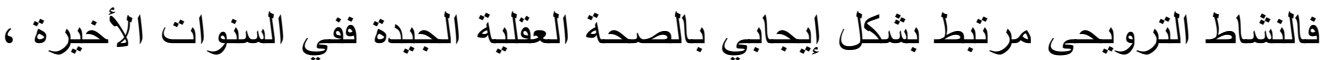

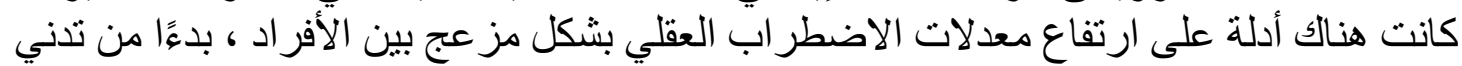

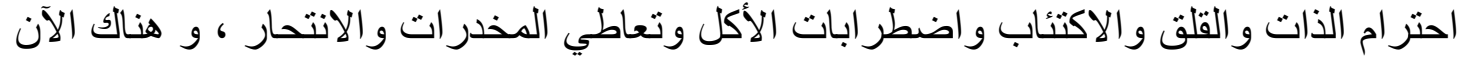
دليل ثابت على أن النشاط الترويحى يمكن أن يكون له تأثير إيجابي على السلامة النفسية للممارسين ( $395: 12$ ).

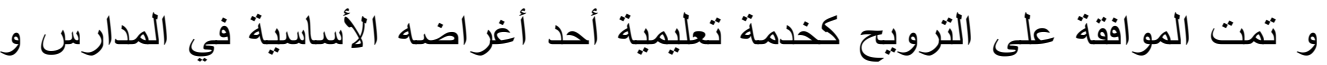

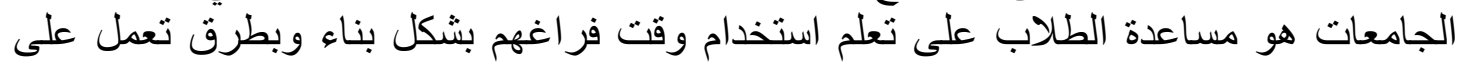

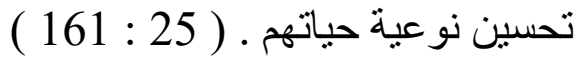

فممارسة الأنشطة الترويحية هى عبارة عن الكفاءات و المهار ات و التصور ات ات الذاتية التي يطور ها الثباب تدريجياً بمرور الوقت ، أو هى قدارة قدرات تسمح بسلوكيات تكيفية وإيجابية تمكن الأفر اد من التعامل بفعالية مع متطلبات وتحديات الحياة اليومية ـ ( 14 : 24 ) و الترويح هو مجمو عة من الأنشطة المختلفة وما يتضمنة من المعرفة و المهار ات و الفهم لهذه الأنشطة ، يهتم بمعرفة الفرد وقدر اته مثل المهار ات الاجتماعية ـ ( 21 : 129 ) و هو تلك الأوجه أو النشاط الذى يكتسب فى وقت الفر اغ ، و التي يتم إختيار هاوفقاء لإر ادة التها الفرد وذللك بغرض تحقيق السرور و المتعه لذاته و إكتساب العديد من القيم الثخصية و الإجتماعية.

و يحتوي الترويح على أنشطة إنسانية وخبرات تحدث في أوقات الفراغ و وعادة ما يتم

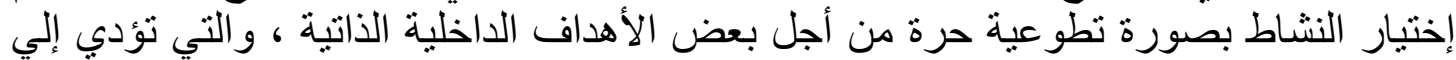

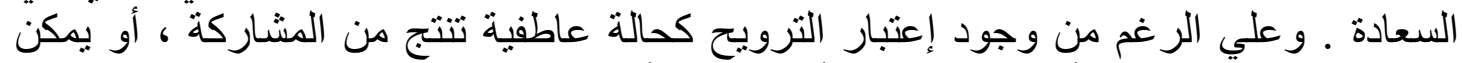

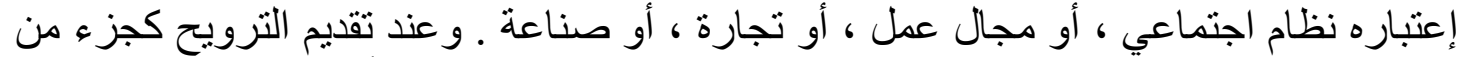

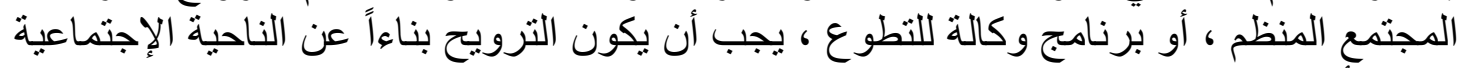

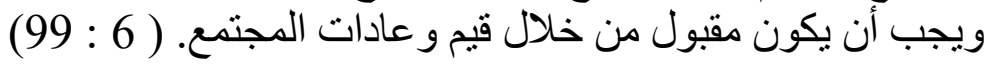

و توجد العديد من الانتطة الترويحية التى بمكن ممارستها فى وقت الفراغ وقد اخد اختلف

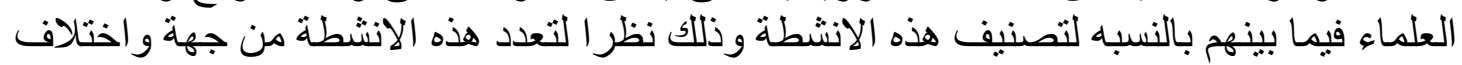

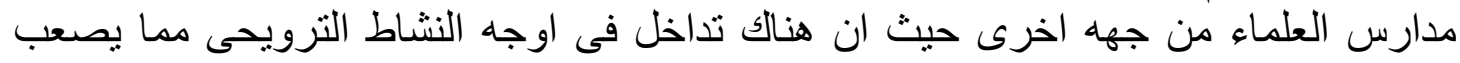

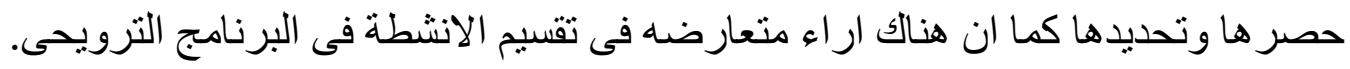


(29:9)

فالأنشطة الترويحية لديها القدرة على تحسين وتثثيط نمو الفرد الثخصي ، حيث أن لايها

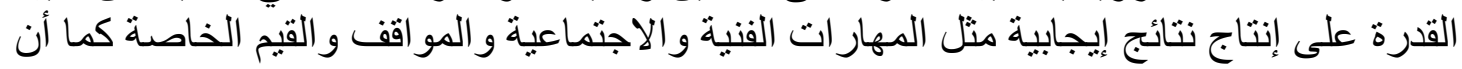

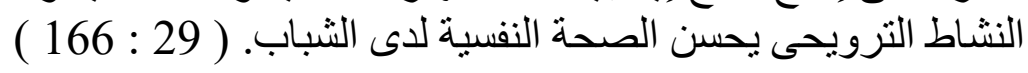

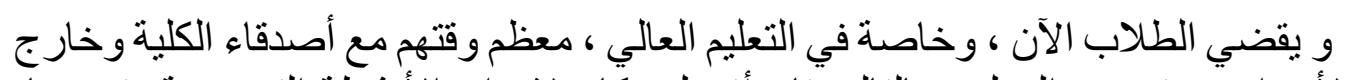

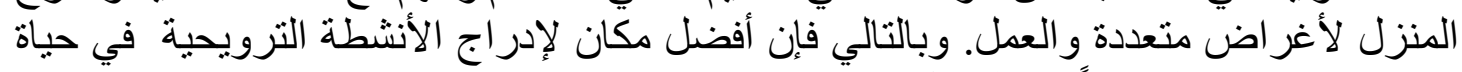

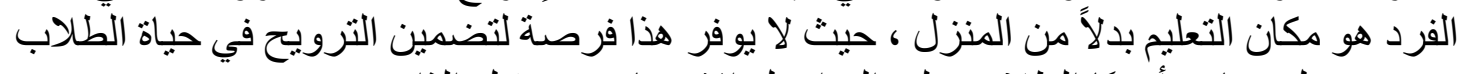
فحسب ، بل يساعد أيضًا الطلاب على المنز التو اصل الاجتماعي و تقبل الذات. ( $2: 33$ )

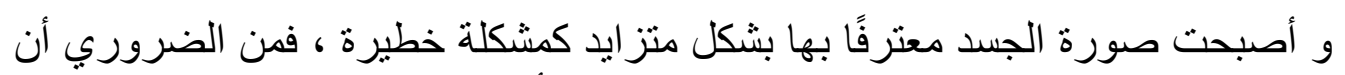

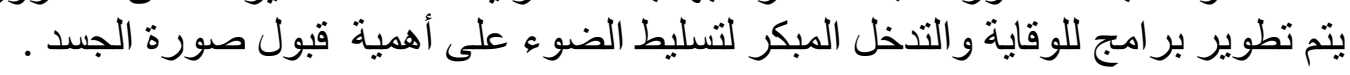
( $11: 35)$

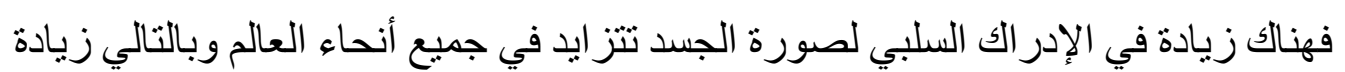

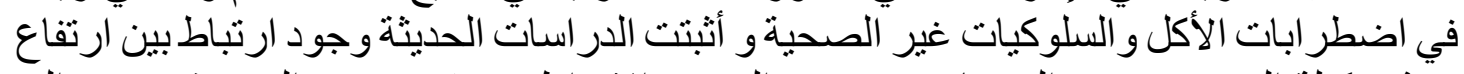

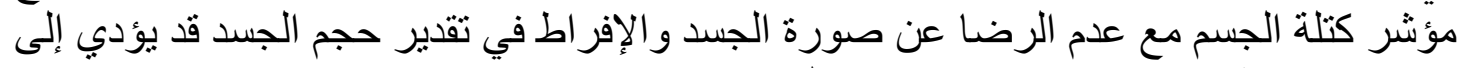

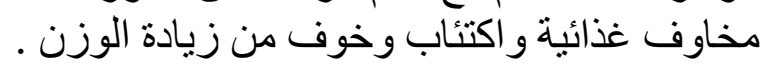

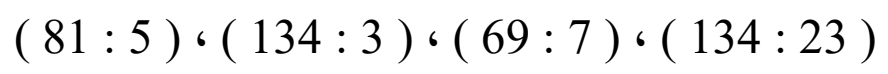

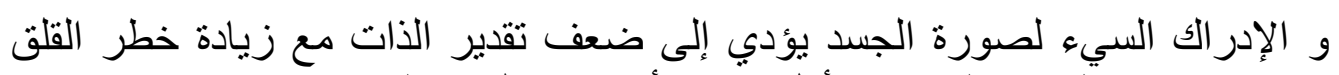

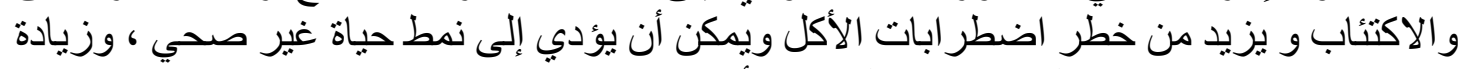

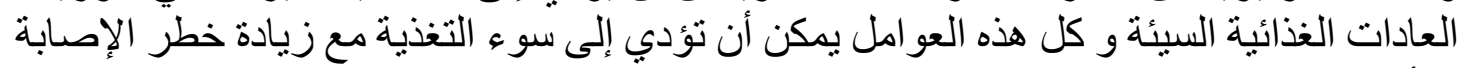

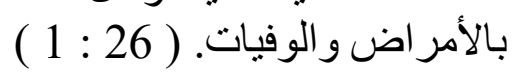

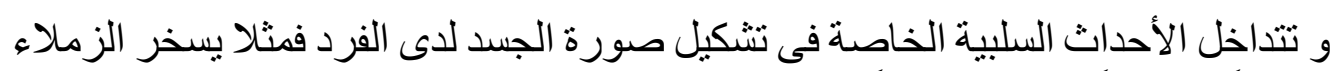

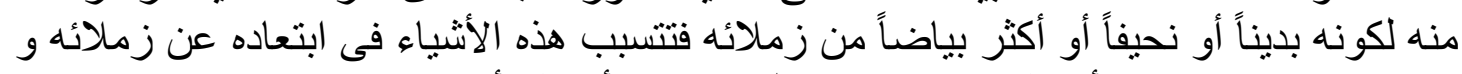

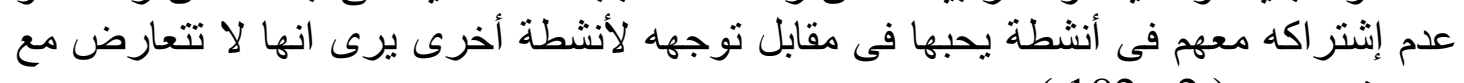
صورة جسده. ( $182: 2$ )

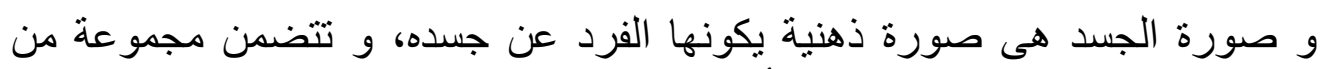

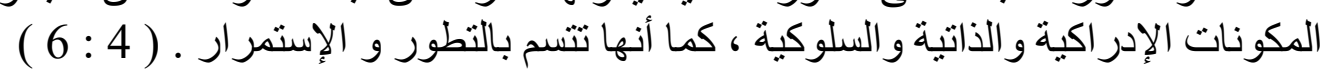

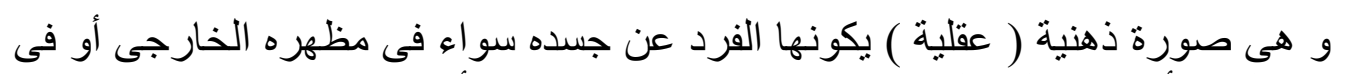

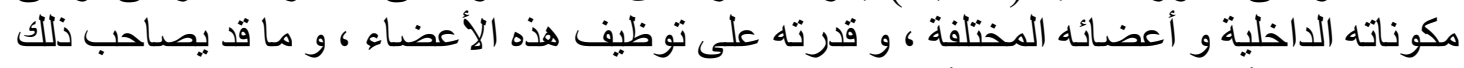

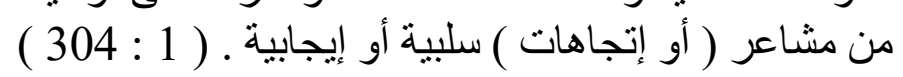

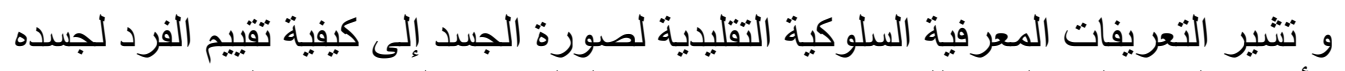

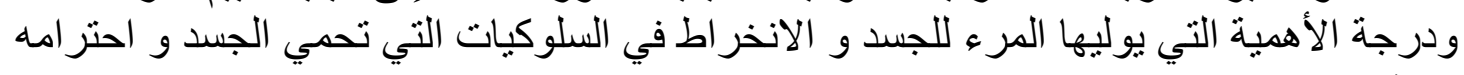
وتغذيته. ( 24 و 9 )

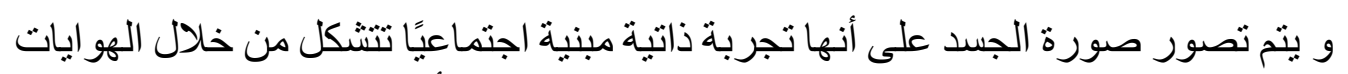

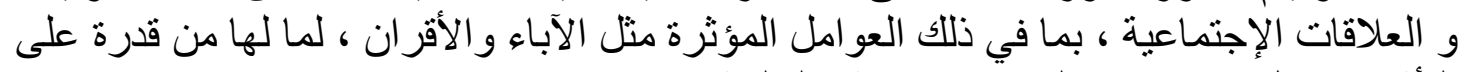
التأثير في كل من صورة الجسم الإيجابية والسلبية. ( 34 : 118 ) 
فمخاوف صورة الجسد منتشرة بطريقة كبيرة جدا بين الأفراد و يمكن المساعدة في

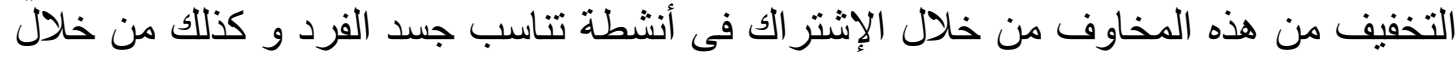

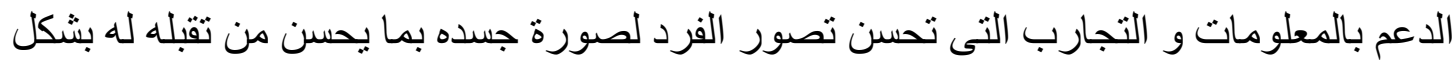

خاص و تقبله للحياة بشكل عام ـ ( 19 : 1 )

يتضح من العرض السابق أهمية الترويح للحد من المظاهر السلبية لوقت الفراغ و و كذللك

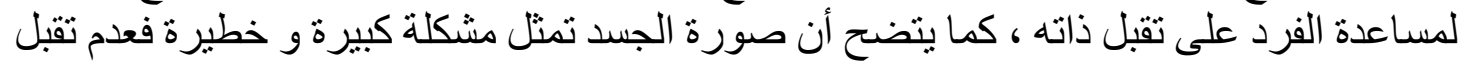

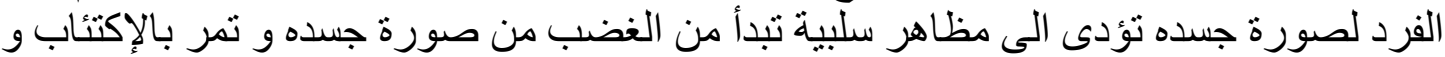

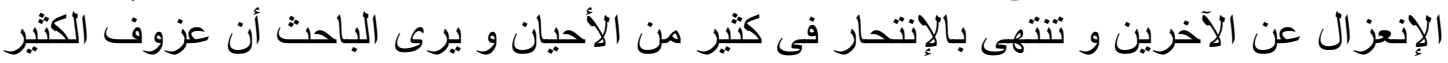

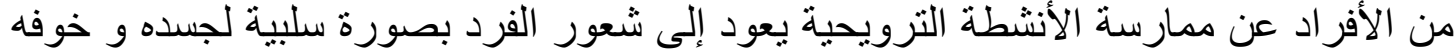

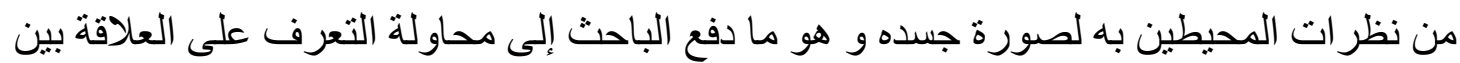

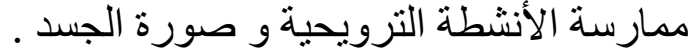

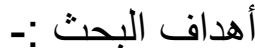

يهذف البحث إلى التعرف على تأثير ممارسة الأنشطة الترويحية فى تقبل صورة الجسدو ذلك من خلال التعرف على : لت التى

ا ـ الفروق بين الممارسين و الغير ممارسين للأنشطة الترويحية فى تقبل صورة الجسد .

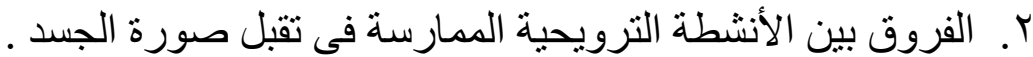

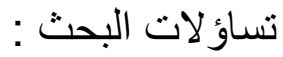

ا ـ هل توجد فروق بين الممارسين و الغير ممارسين للأنشطة الترويحية فى تقبل صورة

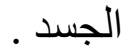
r. هل توجد فروق بين الأنشطة الترويحية الممارسة فى تقبل صورة الجسد .

$$
\text { أو لاً منهج البحث : }
$$

إستخدم الباحث المنهج الوصفى بالأسلوب المسحى .

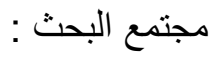

طلاب كلية التربية الرياضية بنين جامعة الإسكندرية للعام الجامعى 2019 / 2020 ـ

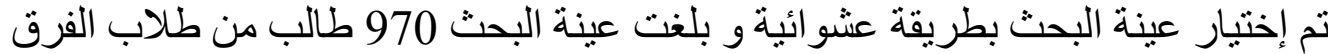
الأربعة بكلية التربية الرياضية بنين جامعة الإسكندرية بنسبة 29 \% من إجمالى طلاب الكلية و طنية 
البالغ عددهم 3310 طالب و تم التوصل للأنشطة الترويحية الممارسة و توزيع العينة على الأنثطة من خلال البيانات الأساسية للعينة و الجدول التالى يوضح توصيف العينة :

جدول (1) عينة البحث موزعة على الدراسة الاستطلاعية والاراسة الأساسية

\begin{tabular}{|c|c|c|c|c|c|c|}
\hline \multicolumn{2}{|c|}{ عينة الدراسة الأساسية } & \multicolumn{2}{|c|}{ عينة الدراسة الاستطلاعية } & \multicolumn{2}{|c|}{ عينة البحثث الكلية } & \multirow{2}{*}{ الممارسة } \\
\hline النسبة \% & 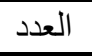 & 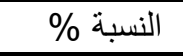 & 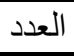 & 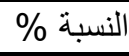 & 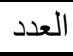 & \\
\hline 95.05 & 173 & 4.95 & 9 & 18.76 & 182 & الاجتماعى \\
\hline 95.13 & 215 & 4.87 & 11 & 23.30 & 226 & الرياضى - الري \\
\hline 95.20 & 119 & 4.80 & 6 & 12.89 & 125 & الفنى - l الفى \\
\hline 95.14 & 137 & 4.86 & 7 & 14.85 & 144 & 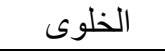 \\
\hline 94.74 & 162 & 5.26 & 9 & 17.63 & 171 & الثقافى \\
\hline 95.08 & 116 & 4.92 & 6 & 12.58 & 122 & الغير ممارس \\
\hline 95.05 & 922 & 4.95 & 48 & 100 & 970 & المجموع \\
\hline
\end{tabular}

يتضح من جدول (1) و الخاص بعينة البحث موز عة على الدر اسة الاستطلاعية و الدر اسة البة

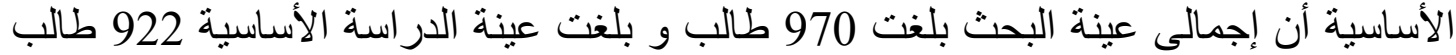

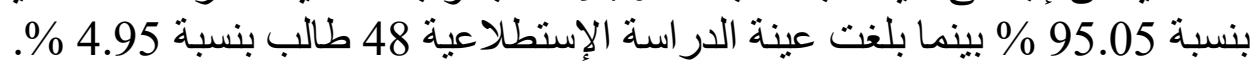

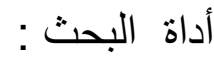
مقياس صورة الجسد ملحق ( 1 ( ) : تم الاعتماد على مقياس محمد على النوبى (12011) ) ( 8 ) ) كأداة لجمع البيانات .

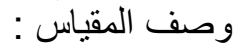

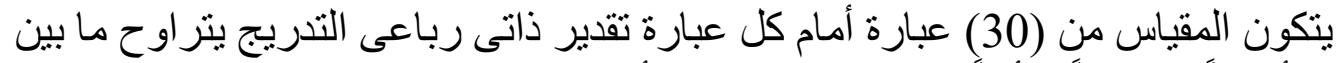

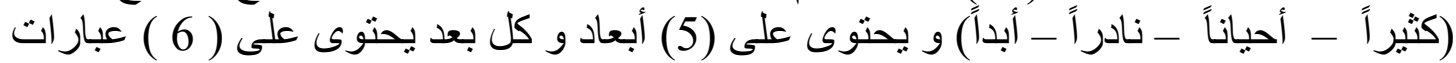
و الجدول التالى يوضح وصف المقياس : جدول ( 2 ) وصف مقياس صورة الجسد

\begin{tabular}{|c|c|c|}
\hline عدد العبارات & أرقام العبارات و إتجاهها & الأبعاد \\
\hline 6 & $26+$ ، $21-$ ، $16+$ ، $11-$ - 6 - ، $1-$ & تقبل أجزاء الجسم المعيبة . \\
\hline 6 & 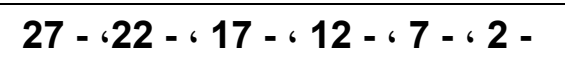 & التناست العام لأجزاء الجسم . \\
\hline 6 & 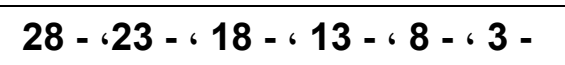 & المنظور النفسى لثكل الجسم . \\
\hline 6 & 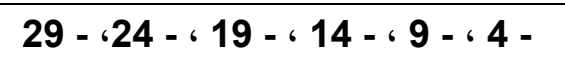 & المنظور الإجتماعى لثكل الجسم . \\
\hline 6 & 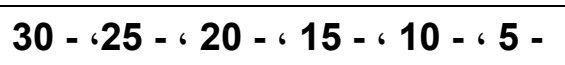 & المحتوى الفكرى لشكل الجسم . \\
\hline \multicolumn{2}{|r|}{30} & عدد الفقرات الكلى \\
\hline
\end{tabular}

المعاملات العلمية لمقياس صورة الجسد : -

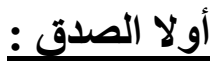

تم حساب الصدق باستخدام طريقة الاتساق الداخلي عن طريق حساب معاملات الارتباط

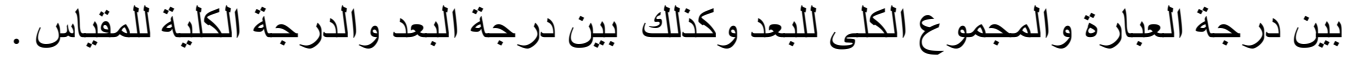


جدول (3) معامل الاتساق الداخلي (معامل ارتباط درجة العبارة بالمجموع الكلى للبعد الأى تنتهى

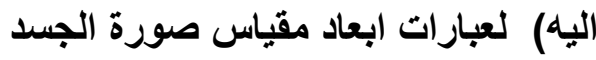

$48=ن$

\begin{tabular}{|c|c|c|c|}
\hline معامل الإتساق & 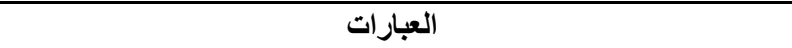 & $\vec{s}$ & البعد \\
\hline${ }^{* *} 0.654$ & أنظر إلى شكلي نظرة سلبية . & 1 & \multirow{6}{*}{ الجسم المعيبة أجزاء } \\
\hline${ }^{* *} 0.657$ & أحاول تجنب النظر في المر آه & 6 & \\
\hline${ }^{* *} 0.599$ & أشعر بعدم الرضـا عن جسمى. & 11 & \\
\hline${ }^{* *} 0.732$ & أتقبل جسمى كما هو عليه . & 16 & \\
\hline${ }^{* *} 0.640$ & أعتقد بأن هناك تشو هات فى جسمى . & 21 & \\
\hline **0.725 & أرى أننى أتتنع بالقبول لدى الناس . & 26 & \\
\hline${ }^{* *} 0.638$ & أرى أنني مقيد الحركة بسبب جسمى. & 2 & \multirow{6}{*}{ لأجزاء التناسث العسم } \\
\hline **0.584 & أشعر أن اجز اء من جسمي مختلفة عن الآخرين . & 7 & \\
\hline${ }^{* *} 0.643$ & أتجنب الحركة الكثبرة لعدم وجود تناسق بين أجزاء جسمى . & 12 & \\
\hline${ }^{* *} 0.588$ & أشعر بأنه من الأفضل إجر اء تغيير فى شكلى . & 17 & \\
\hline${ }^{* *} 0.672$ & أحتاج لجر احة تجميلية لإحداث تناسق فى جسمى (شكلى ) . & 22 & \\
\hline **0.590 & أعتقد أن الناس يبتعدون عنى لأن شكلى غريب . & 27 & \\
\hline${ }^{* *} 0.643$ & أميل لتغيير بعض ملامح وجهى . & 3 & \multirow{6}{*}{ الثنظور الجسمى } \\
\hline${ }^{* *} 0.645$ & أشعر بأنني غير قادر على فهم طبيعة جسمى. & 8 & \\
\hline${ }^{* *} 0.707$ & أرى أن ملابسى أكثر وجاهه من زملائى . & 13 & \\
\hline${ }^{* *} 0.641$ & أرى أن هناك تناقضاً بين أفكارى و شكل جسمى . & 18 & \\
\hline${ }^{* *} 0.720$ & أفتقز إلى الثقة بشكلى. & 23 & \\
\hline${ }^{* *} 0.708$ & أشعر بالقلق حول عيوبى الجسمية . & 28 & \\
\hline${ }^{* *} 0.748$ & أفضل البقاء في المنزل عن الذهاب في رحلة مع أصدقائى بسبب جسمى. & 4 & \multirow{6}{*}{ لشنَل الإجتماعى الجسى } \\
\hline${ }^{* *} 0.633$ & أنفادى حضور المناسبات الاجتماعية كالأفراح. & 9 & \\
\hline${ }^{* *} 0.728$ & أرفض ارتداء الملابس الضيقة بسبب شكل جسمى . & 14 & \\
\hline${ }^{* *} 0.661$ & أشُعر بالاحر اج من مظهرى عند خروجى مع زملائى. & 19 & \\
\hline **0.651 & أتجنب الإختلاط بالناس لشعورى بعدم قبولهم شكلى . & 24 & \\
\hline **0.628 & لا أستطيع البقاء طو يلاً فى مكان يتو اجد به الناس. & 29 & \\
\hline${ }^{* *} 0.667$ & أشعر أن الناس لا بروننى جذاباً. & 5 & \multirow{6}{*}{ الفكرى الثكل } \\
\hline${ }^{* *} 0.681$ & أحزن عند النظر إلى جسمى في المر آه. & 10 & \\
\hline${ }^{* *} 0.693$ & أرى أن شكلى بشع و مقزز . & 15 & \\
\hline${ }^{* *} 0.661$ & يقلقى مظهر جسمى . & 20 & \\
\hline${ }^{* *} 0.736$ & أحكم على الناس تبعاً لشكل أجسامهم . & 25 & \\
\hline${ }^{* *} 0.658$ & أعجز عن التفاعل مع الناس بطريقة طبيعية بسبب جسمى & 30 & \\
\hline
\end{tabular}

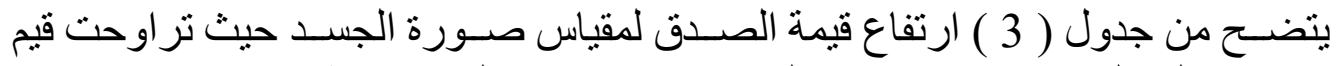

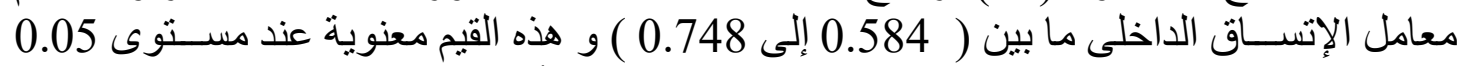
مما يدل على صدق المقياس و إرتباط عبار ات المقياس مع الأبعاد التى تنتمى اليها .

جدول (4) معامل الاتساق الاخلي (معامل ارتباط درجة البعد بالمجموع الكلى للمقياس) لابعاد مقياس صورة الجسد

$48=\dot{0}$

\begin{tabular}{|c|c|}
\hline معامل الاتساق الداخلي & الابعاد \\
\hline **0.686 & تقبل أجزاء الج \\
\hline
\end{tabular}




\begin{tabular}{|c|c|}
\hline${ }^{* *} 0.741$ & التناسث العام لأجزاء الجسم \\
\hline${ }^{* *} 0.770$ & المنظور النفسى لشكل الجسم \\
\hline${ }^{* *} 0.709$ & المنظور الإجتماعى لشكل الجسم \\
\hline **0.764 & المحتوى الفكرى لثكل الجسم \\
\hline
\end{tabular}

يتضح من جدول ( 4 ) ارتفاع قيمة الصدق للأبعاد حيث تر اوحت قيم معامل الإتسـاق ما

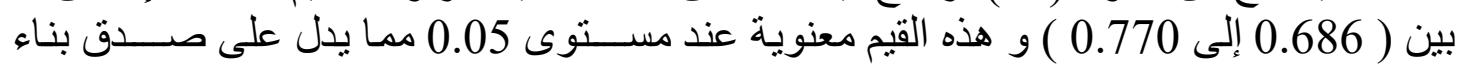
المقياس و أنه يقيس ما وضع من أجله

ثانياً : الثبات:

قام الباحث بحساب ثبات مقياس صورة الجسد البحث ، باستخدام معامل الفا لكرونباك و طريقة اعادة التطبيق على العينة الاستطلاعية التى قوامها (48) طالب من خارج جان عينة البحث

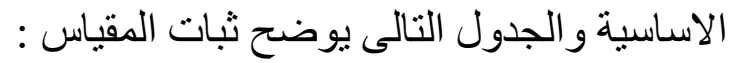

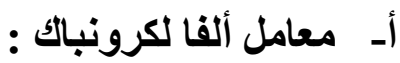

جدول ( 5 ) معامل الفا لكرونباك لابعاد مقياس صورة الجسد

$48=\dot{ن}$

\begin{tabular}{|c|c|c|}
\hline \multicolumn{2}{|c|}{ معامل الفا لكرونباك } & \multirow{2}{*}{ 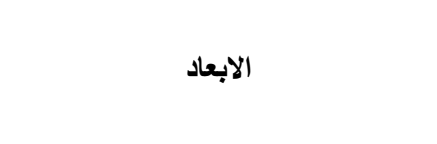 } \\
\hline للمقياس ككل & 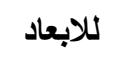 & \\
\hline \multirow{5}{*}{0.819} & 0.776 & تقبل أجزاء الجسم المعيبة \\
\hline & 0.758 & التناست العام لأجزاء الجسم \\
\hline & 0.748 & المنظور النفسى لثكل الجسم \\
\hline & 0.760 & المنظور الإجتماعى لشكل الجسم \\
\hline & 0.741 & المحتوى الفكرى لثكل الجسم \\
\hline
\end{tabular}

يتضح من جدول ( 5 ) و الخاص بحسـاب الثبات عن طريق معامل ألفا بالنسبة للأبعاد أن

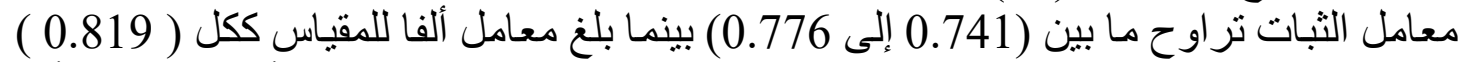

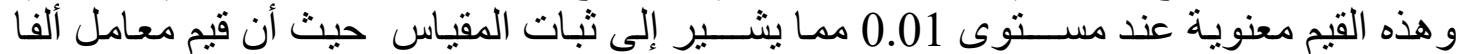

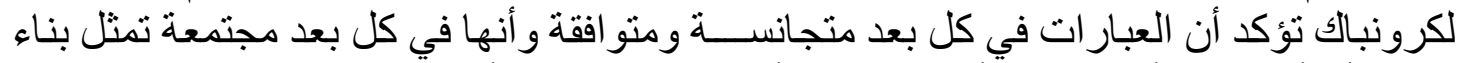

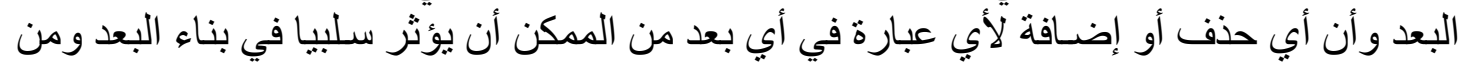

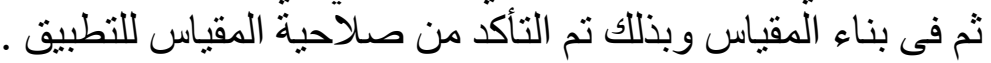

ب- ثبات التطبيق و اعادة التطبيق:

قام الباحث بحساب ثبات مقياس صورة الجسد عن طريق التطبيق و إعادة التطبيق بعد مدة

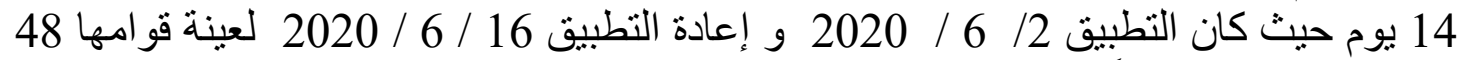

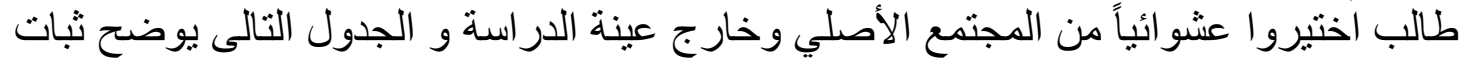
التطبيق و اعادة التطبيق إنبرأ من 
جدول (6) الفروق بين التطبيق و إعادة التطبيق للعينة الاستطلاعية لإيجاد ثبات اعادة تطبيق أبعاد مقياس مقياس صورة الجسد التطبئ الاستطلة

$48=ن$

\begin{tabular}{|c|c|c|c|c|c|c|c|c|}
\hline \multirow{2}{*}{ الثبات } & \multirow{2}{*}{ قيمة } & \multicolumn{2}{|c|}{ الفرق بين المتوسطين } & \multicolumn{2}{|c|}{ إعادة التطبيق } & \multicolumn{2}{|c|}{ 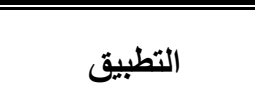 } & \multirow{2}{*}{ الأبعاد } \\
\hline & & $\varepsilon \pm$ & س & $\varepsilon \pm$ & س & $\varepsilon \pm$ & س & \\
\hline 0.909 & 1.70 & 0.42 & 0.10 & 3.63 & 18.75 & 3.58 & 18.65 & تقبل أجزاء الجسم المعيبة \\
\hline 0.879 & 0.82 & 0.88 & 0.10 & 3.44 & 19.02 & 3.64 & 18.92 & التناسق العام لأجزاء الجسم \\
\hline 0.932 & 1.70 & 2.46 & 0.60 & 4.31 & 17.48 & 4.24 & 16.88 & المنظور النفسى لشكل الجسم \\
\hline 0.941 & 1.62 & 1.78 & 0.42 & 4.55 & 18.17 & 4.43 & 17.75 & المنظور الإجتماعى لشكل الجسم \\
\hline 0.888 & 1.62 & 1.34 & 0.31 & 4.33 & 16.85 & 4.15 & 16.54 & المحتوى الفكرى لشكل الجسم \\
\hline 0.901 & 1.66 & 6.42 & 1.54 & 17.81 & 90.27 & 17.33 & 88.73 & مجموع المقياس \\
\hline
\end{tabular}

يتضح من جدول (6) و الخاص بالفروق بين التطبيق و إعادة التطبيق للعينة الاستطلاعية

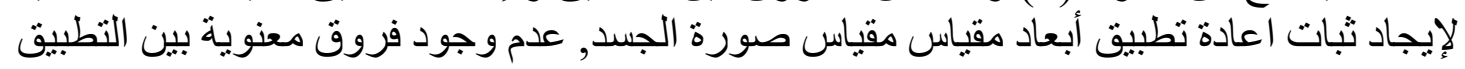

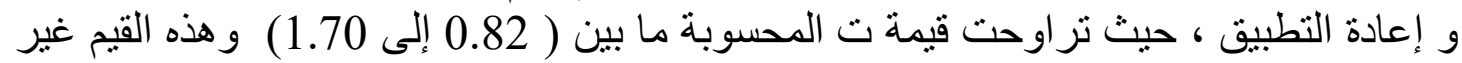

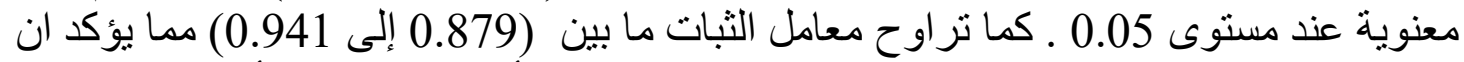
مقياس صورة الجسد يتسم بالثبات وانه يعطى نفس النتائج إذا أعيد تطبيقه مرة أخرى على على نفس

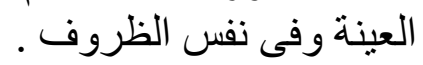

تم وضــــع أربعة بدائل بطريقة ليكرت و هى (كثيراً - أحياناً - نادراً - أبداً ) أمام كل تصحيح المقياس :

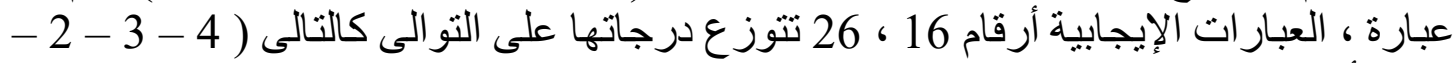

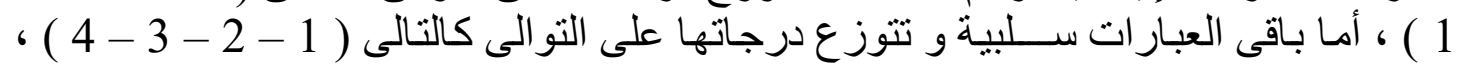

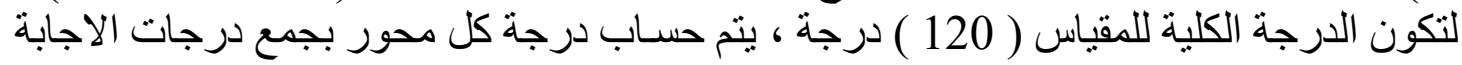

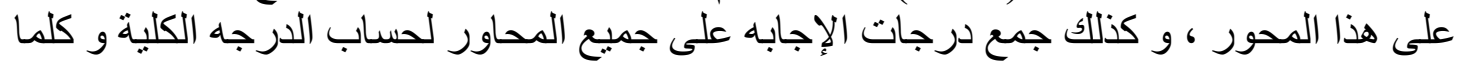

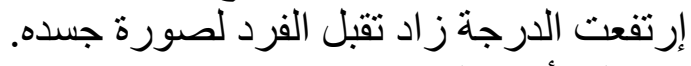

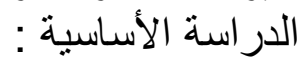

قام الباحث بتطبيق مقياس صورة الجسد على عينة الدراسة الأساسية فى الفترة من

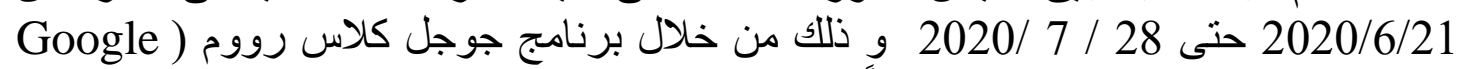
(Classroom

$$
\begin{aligned}
& \text { كورونا . }
\end{aligned}
$$

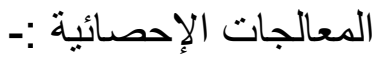

قام الباحث بمعالجة بيانات الدراسة باستخدام برنامج 20 IBM SPSS Statistics

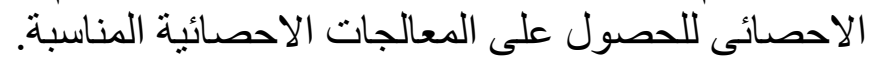

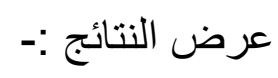

جدول (7) تحليل التباين (ANOVA) بين الممارسين وغير الممارسين للأنثطة الترويحية في ابعاد

\begin{tabular}{|c|c|c|c|c|c|c|c|}
\hline الدلالة & المعنوية & قيمة ف & المربعات & المربعوع & الحرية & مصدر التباين & المتغيرات \\
\hline دال & 0.00 & ${ }^{*} 606.41$ & 2643.89 & 13219.47 & 5 & بين المجموعات & تقبل أجزاء الجسم المعيبة \\
\hline
\end{tabular}
ومجموع مقياس صورة الجسد 


\begin{tabular}{|c|c|c|c|c|c|c|c|}
\hline & & & 4.36 & 3993.65 & 916 & داخل المجموعات & \\
\hline & & & & 17213.12 & 921 & المجموع & \\
\hline \multirow[t]{3}{*}{ دال } & 0.00 & *514.15 & 2429.03 & 12145.16 & 5 & بين المجموعات & \multirow{3}{*}{ التناسق العام لأجزاء الجسم } \\
\hline & & & 4.72 & 4327.52 & 916 & داخل المجموعات & \\
\hline & & & & 16472.68 & 921 & المجموع & \\
\hline \multirow[t]{3}{*}{ دال } & 0.00 & *1158.32 & 2913.02 & 14565.11 & 5 & بين المجموعات & \multirow{3}{*}{ المنظور النفسى لشكل الجسم } \\
\hline & & & 2.51 & 2303.61 & 916 & داخل المجموعات & \\
\hline & & & & 16868.72 & 921 & المجموع & \\
\hline \multirow[t]{3}{*}{ 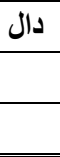 } & 0.00 & *798.94 & 2955.48 & 14777.42 & 5 & بين المجموعات & \multirow{3}{*}{ المنظور الإجتماعى لشكل الجسم } \\
\hline & & & 3.70 & 3388.52 & 916 & داخل المجموعات & \\
\hline & & & & 18165.94 & 921 & المجموع & \\
\hline \multirow[t]{3}{*}{ دال } & 0.00 & *891.60 & 3174.13 & 15870.65 & 5 & بين المجموعات & \multirow{3}{*}{ المحتوى الفكرى لشكل الجسم } \\
\hline & & & 3.56 & 3261.01 & 916 & داخل المجموعات & \\
\hline & & & & 19131.65 & 921 & المجموع & \\
\hline \multirow[t]{3}{*}{ دال } & 0.00 & *1931.35 & 61820.40 & 309102.01 & 5 & بين المجموعات & \multirow{3}{*}{ المجموع الكلى للمقياس } \\
\hline & & & 32.01 & 29320.16 & 916 & داخل المجموعات & \\
\hline & & & & 338422.17 & 921 & المجموع & \\
\hline
\end{tabular}

$$
2.10=0.05 \text { معنوى عند مستوى" }
$$

يتضح من جدول (7) والخاص بتحليل التباين (ANOVA) بين الممارسين وغير

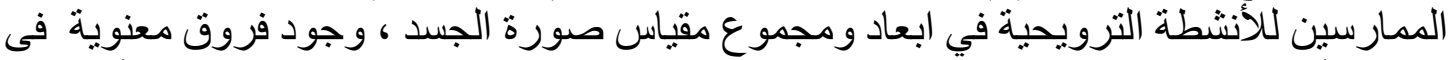

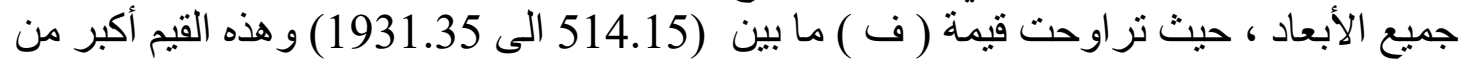
قيمة (ف) الجدولية عند مستوى (0.05)، ولتحديد معنوية الفروق تم استخدام اختبار اقل فرق

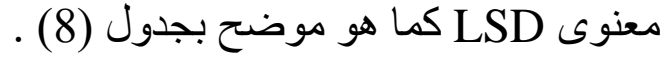

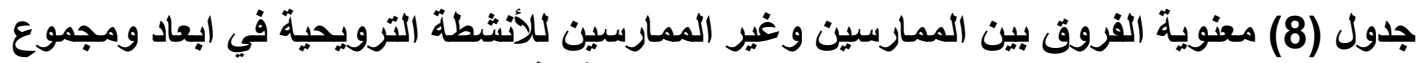

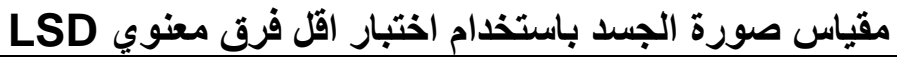

\begin{tabular}{|c|c|c|c|c|c|c|c|c|c|c|}
\hline \multirow{2}{*}{$\begin{array}{l}\text { قيمة } \\
\text { LSD }\end{array}$} & \multicolumn{6}{|c|}{ دلالة الفروق بين المتوسطات } & \multirow{2}{*}{ الالتجيراف } & \multirow{2}{*}{ الحستبي } & \multirow{2}{*}{ الممارسين } & \multirow{2}{*}{ غيرات } \\
\hline & الغير ممارس & الثقافي & 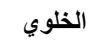 & الفني & الرياضي & الاجتماعي & & & & \\
\hline \multirow[t]{3}{*}{0.47} & $* 10.55$ & *3.87 & ${ }^{*} 0.52$ & 0.14 & *1.56 & & 1.81 & 21.10 & الاجتماعي & \multirow{3}{*}{ جسم أجزاء } \\
\hline & *12.11 & *5.43 & *2.08 & *1.42 & & & 1.37 & 22.66 & الرياضي & \\
\hline & *10.69 & *4.01 & ${ }^{*} 0.66$ & & & & 3.01 & 21.24 & القني & \\
\hline
\end{tabular}




\begin{tabular}{|c|c|c|c|c|c|c|c|c|}
\hline & $* 10.03$ & 3.35 & & & & 3.18 & 20.58 & الظلوي \\
\hline & ${ }^{*} 6.68$ & & & & & 1.29 & 17.23 & الثقافي \\
\hline & & & & & & 1.64 & 10.55 & الغير ممارس \\
\hline \multirow[t]{6}{*}{0.49} & ${ }^{*} 11.10$ & *4.34 & *1.72 & *1.22 & 0.28 & 2.21 & 21.79 & الاجتماعي \\
\hline & *11.38 & *4.62 & *2.00 & $* 1.50$ & & 2.02 & 22.07 & الرياضي \\
\hline & ${ }^{*} 9.88$ & $* 3.12$ & ${ }^{*} 0.50$ & & & 2.85 & 20.57 & الفني \\
\hline & *9.38 & *2.62 & & & & 3.00 & 20.07 & الخلوي \\
\hline & ${ }^{*} 6.76$ & & & & & 1.22 & 17.45 & الثقافي \\
\hline & & & & & & 1.29 & 10.69 & الغير ممارس \\
\hline \multirow[t]{6}{*}{0.36} & *8.65 & *2.02 & *3.51 & *2.73 & *4.41 & 1.15 & 18.71 & الاجتماعي \\
\hline & *13.06 & ${ }^{*} 6.43$ & *7.92 & *7.14 & & 1.46 & 23.12 & الرياضي \\
\hline & $* 5.92$ & ${ }^{*} 0.71$ & $* 0.78$ & & & 1.81 & 15.98 & الفني \\
\hline & *5.14 & *1.49 & & & & 2.08 & 15.20 & الخلوي \\
\hline & *6.63 & & & & & 1.43 & 16.69 & الثقافي \\
\hline & & & & & & 1.66 & 10.06 & الغير ممارس \\
\hline \multirow[t]{6}{*}{0.44} & *10.35 & *3.86 & *4.71 & *4.21 & *2.44 & 2.71 & 20.80 & الاجتماعي \\
\hline & *12.79 & ${ }^{*} 6.30$ & ${ }^{*} 7.15$ & ${ }^{*} 6.65$ & & 1.23 & 23.24 & الرياضي \\
\hline & ${ }^{*} 6.14$ & 0.35 & ${ }^{*} 0.50$ & & & 1.50 & 16.59 & الفني \\
\hline & *5.64 & ${ }^{*} 0.85$ & & & & 1.87 & 16.09 & الخلوي \\
\hline & ${ }^{*} 6.49$ & & & & & 1.53 & 16.94 & الثقافي \\
\hline & & & & & & 2.44 & 10.45 & الغير ممارس \\
\hline \multirow[t]{6}{*}{0.43} & *5.12 & *1.27 & *0.85 & ${ }^{*}{ }^{* 6.15}$ & ${ }^{* 7.73}$ & 1.96 & 15.09 & الاجتماعي \\
\hline & *12.85 & ${ }^{*} 6.46$ & *6.88 & *1.58 & & 1.42 & 22.82 & الرياضي \\
\hline & *11.27 & *4.88 & *5.30 & & & 2.52 & 21.24 & الفني \\
\hline & $* 5.97$ & 0.42 & & & & 1.49 & 15.94 & الخلوي \\
\hline & $* * 6.39$ & & & & & 1.73 & 16.36 & الثقافي \\
\hline & & & & & & 2.35 & 9.97 & الغير ممارس \\
\hline \multirow[t]{6}{*}{1.29} & *45.77 & *12.81 & *9.61 & $* 1.86$ & $* 16.42$ & 5.24 & 97.49 & الاجتماعي \\
\hline & ${ }^{*} 62.19$ & ${ }^{*} 29.23$ & ${ }^{*} 26.03$ & *18.28 & & 4.76 & 113.91 & الرياضي \\
\hline & *43.91 & *10.95 & ${ }^{*} 7.75$ & & & 6.44 & 95.63 & الفني \\
\hline & $* 36.16$ & $* 3.20$ & & & & 7.81 & 87.88 & الخلوي \\
\hline & *32.96 & & & & & 4.12 & 84.68 & الثقافي \\
\hline & & & & & & 5.77 & 51.72 & الغير ممارس \\
\hline
\end{tabular}

يتضح من جدول (8) و الخاص بمعنوية الفروق بين الممارسين و غير الممارسين للأنشطة

الترويحية في ابعاد و ججموع مقياس صورة الجسد باستخدام اختبار اقل فرق معنوي LSD :

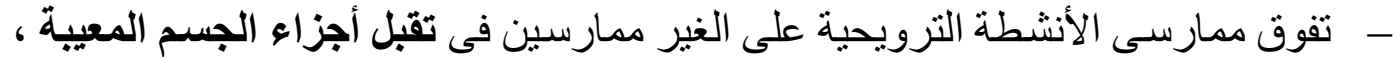

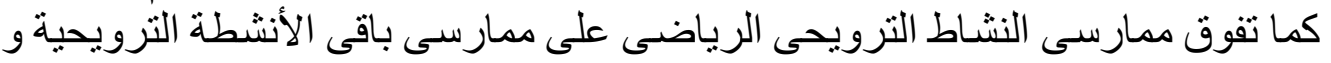

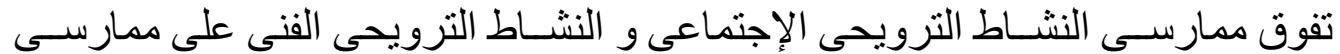

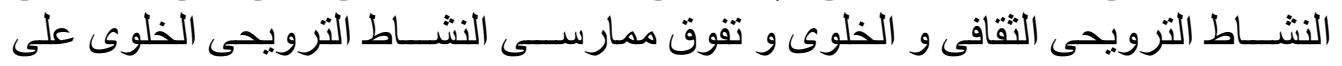

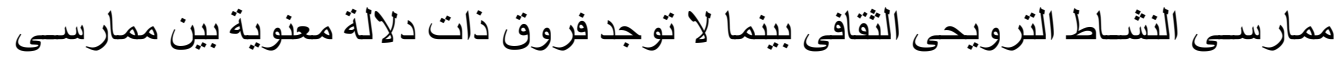

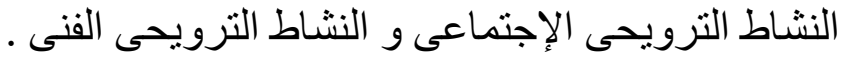


- تفوق ممارسى الأنشطة الترويحية على الغير ممارسين فى التناسق العام لأجزاء الجسم

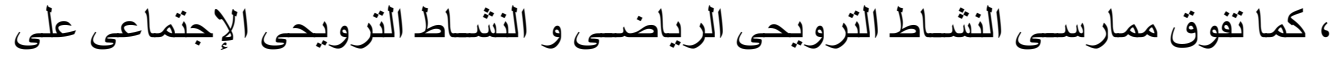

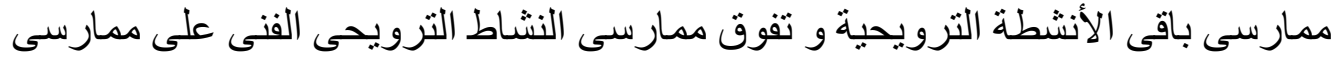

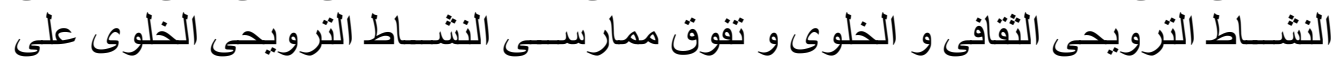

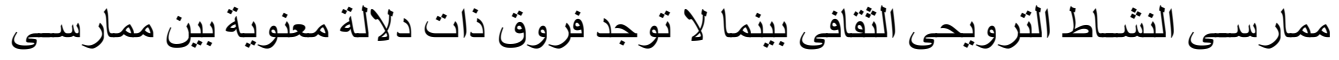

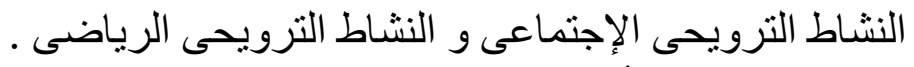

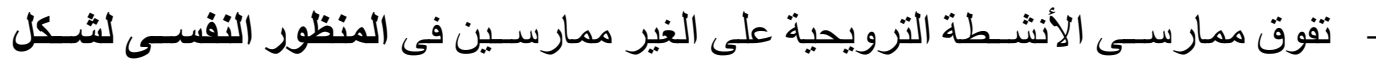

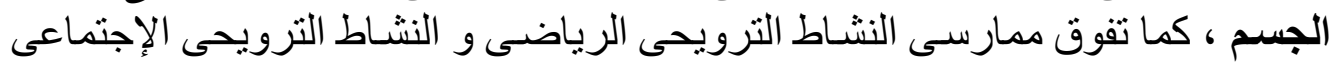

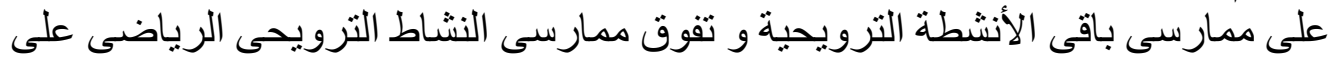

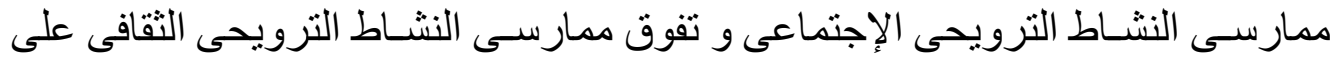
ممارسى النثاط الترويحى الفنى و الخلوى و تفوق ممارسى النشاط الترويحى الفنى على

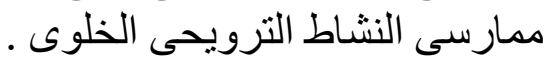
تفوق ممارسـى الأنشـــة الترويحية على الغير ممارسـين في المنظور الإجتماعى لثـــل

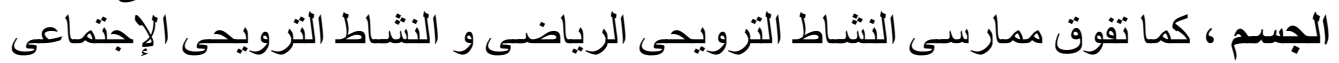

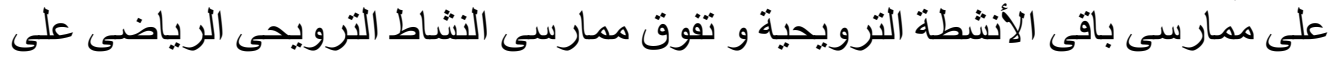

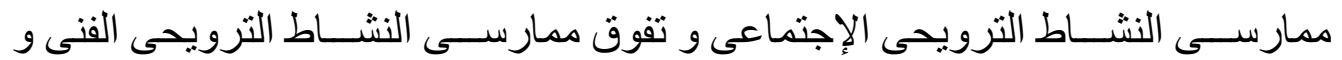

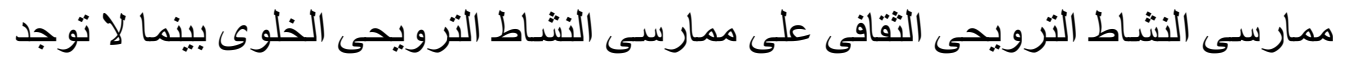

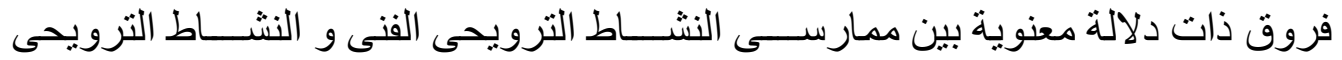
الثقافى. تفوق ممارسـى الأنثـــة الترويحية على الغير ممارسـين فى المحتوى الفكرى لثـــل

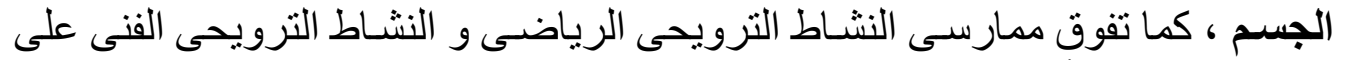

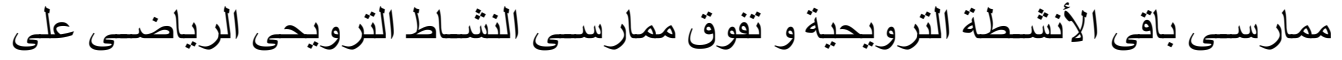

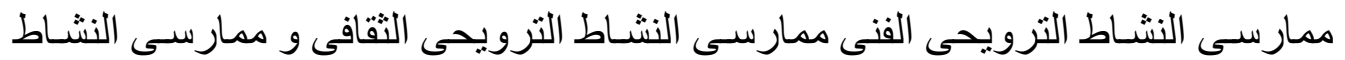

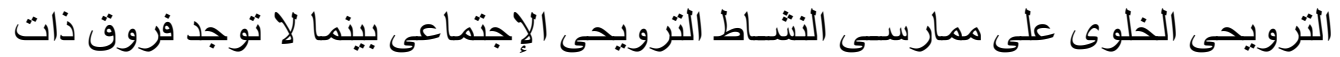

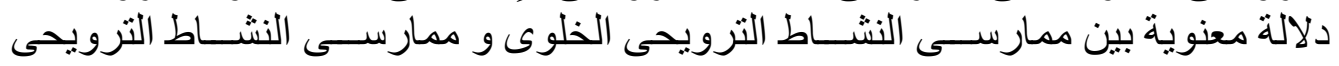
الثقافى.

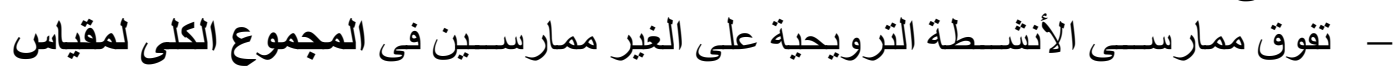

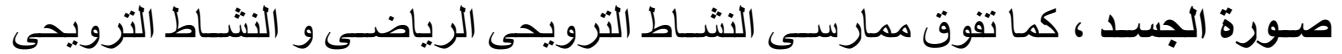

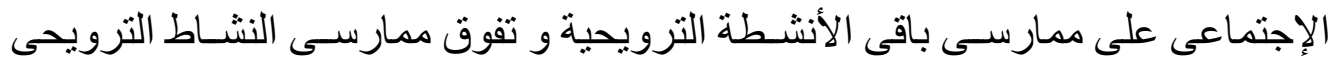

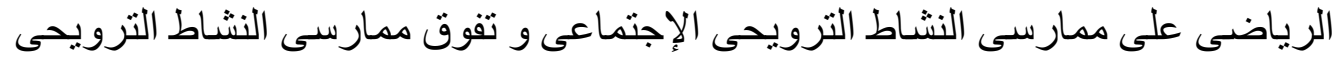

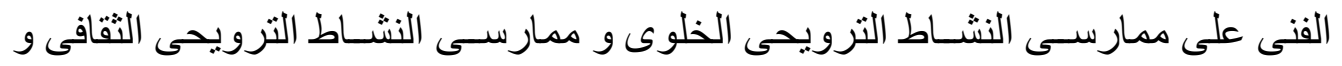
تفوق ممارسى النشاط الترويحى الخلوى على ممارسى النشاط الترويحى الثقافى .

جدول (9) نسبة الفروق \% بين الممارسين وغير الممارسين للأنشطة الترويحية في ابعاد ومجموع

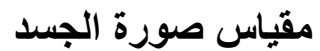

\begin{tabular}{|c|c|c|c|c|c|c|c|c|}
\hline \multicolumn{6}{|c|}{ نسبة الفروق \% بين المجموعات } & \multirow{2}{*}{ الحستبي } & \multirow{2}{*}{ الممارسين } & \multirow{2}{*}{ المتغيرات } \\
\hline الغير ممارس & الثقافي & الخلوي & الفني & الرياضي & الاجتماعي & & & \\
\hline 50.00 & $\overline{~ 18.34}$ & 2.46 & $\bar{~} 0.66$ & 7.39 & & 21.10 & الاجتماعى & \multirow{5}{*}{ تقبل أجزاء الجسم } \\
\hline 53.44 & 23.96 & 9.18 & 6.27 & & & 22.66 & الرياضي & \\
\hline 50.33 & 18.88 & 3.11 & & & & 21.24 & الفني & \\
\hline 48.74 & 16.28 & & & & & 20.58 & الخلوي & \\
\hline 38.77 & & & & & & 17.23 & الثقافي & \\
\hline
\end{tabular}




\begin{tabular}{|c|c|c|c|c|c|c|c|}
\hline & & & & & 10.55 & الغير ممارس & \\
\hline 50.94 & 19.92 & 7.89 & 5.60 & 1.28 & 21.79 & الاجتماعي & \multirow{6}{*}{ التناست العام لأجزاء } \\
\hline 51.56 & 20.93 & 9.06 & 6.80 & & 22.07 & الرياضي & \\
\hline 48.03 & 15.17 & 2.43 & & & 20.57 & الفني & \\
\hline 46.74 & 13.05 & & & & 20.07 & الظلوي & \\
\hline \multirow[t]{2}{*}{38.74} & & & & & 17.45 & الثقافي & \\
\hline & & & & & 10.69 & الغير ممارس & \\
\hline 46.23 & 10.80 & 18.76 & 14.59 & 23.57 & 18.71 & الاجتماعي & \multirow{6}{*}{ الثنظول الجسمى النفس } \\
\hline 56.49 & 27.81 & 34.26 & 30.88 & & 23.12 & الرياضيَ & \\
\hline 37.05 & 4.44 & 4.88 & & & 15.98 & الفني & \\
\hline 33.82 & 9.80 & & & & 15.20 & الخلوي & \\
\hline \multirow[t]{2}{*}{39.72} & & & & & 16.69 & الثقافي & \\
\hline & & & & & 10.06 & الغير ممارس & \\
\hline 499.76 & 18.56 & 22.64 & 20.24 & 11.73 & 20.80 & الاجتماعي & \multirow{6}{*}{ الشكل الجسم الإتماعى } \\
\hline 55.03 & 27.11 & 30.77 & 28.61 & & 23.24 & الرياضي & \\
\hline 37.01 & 2.11 & 3.01 & & & 16.59 & الفني & \\
\hline 35.05 & 5.28 & & & & 16.09 & الخلوي & \\
\hline \multirow[t]{2}{*}{38.31} & & & & & 16.94 & الثقافي & \\
\hline & & & & & 10.45 & الغير ممارس & \\
\hline 33.93 & 8.42 & 5.63 & 40.76 & 51.23 & 15.09 & الاجتماعي & \multirow{6}{*}{ المحتوى الفكرى لثكل } \\
\hline 56.31 & 28.31 & 30.15 & 6.92 & & 22.82 & الرياضي & \\
\hline 53.06 & 22.98 & 24.95 & & & 21.24 & الفني & \\
\hline 37.45 & 2.63 & & & & 15.94 & الظلوي & \\
\hline \multirow[t]{2}{*}{39.06} & & & & & 16.36 & الثقافي & \\
\hline & & & & & 9.97 & الغير ممارس & \\
\hline 46.95 & 13.14 & 9.86 & 1.91 & 16.84 & 97.49 & الاجتماعي & \multirow{6}{*}{ اللمقياس الكلى } \\
\hline 54.60 & 25.66 & 22.85 & 16.05 & & 113.91 & الرياضي & \\
\hline 45.92 & 11.45 & 8.10 & & & 95.63 & الفني & \\
\hline 41.15 & 3.64 & & & & 87.88 & الخلوي & \\
\hline \multirow[t]{2}{*}{38.92} & & & & & 84.68 & الثقافي & \\
\hline & & & & & 51.72 & الغير ممارس & \\
\hline
\end{tabular}

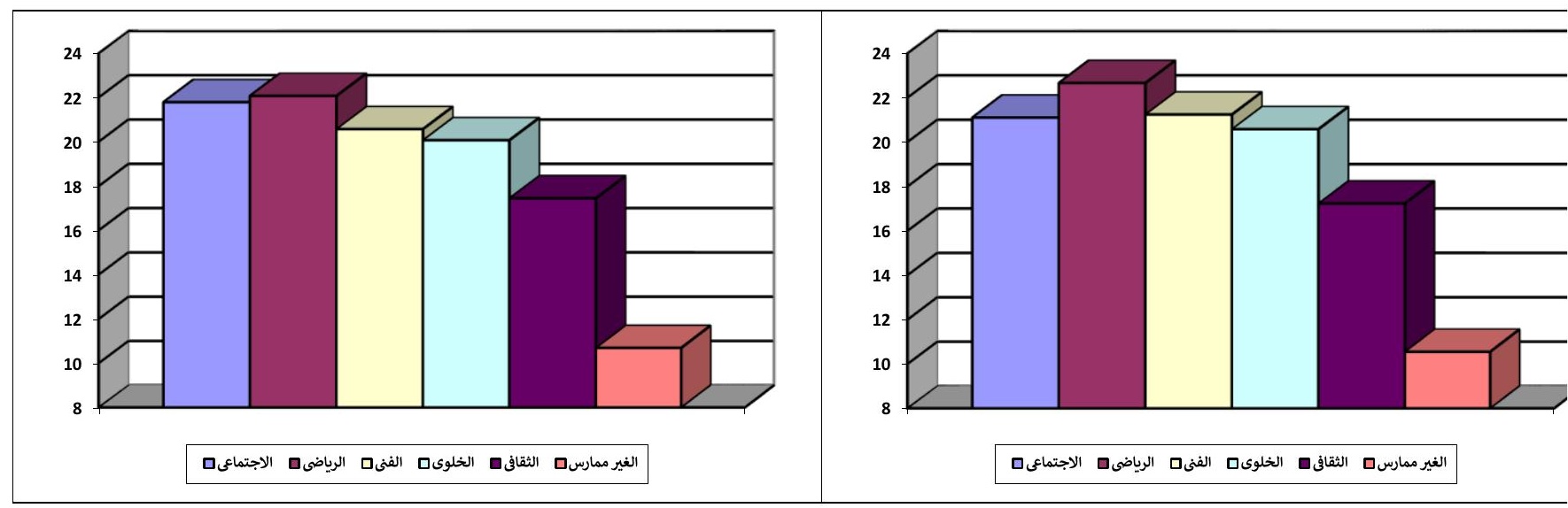




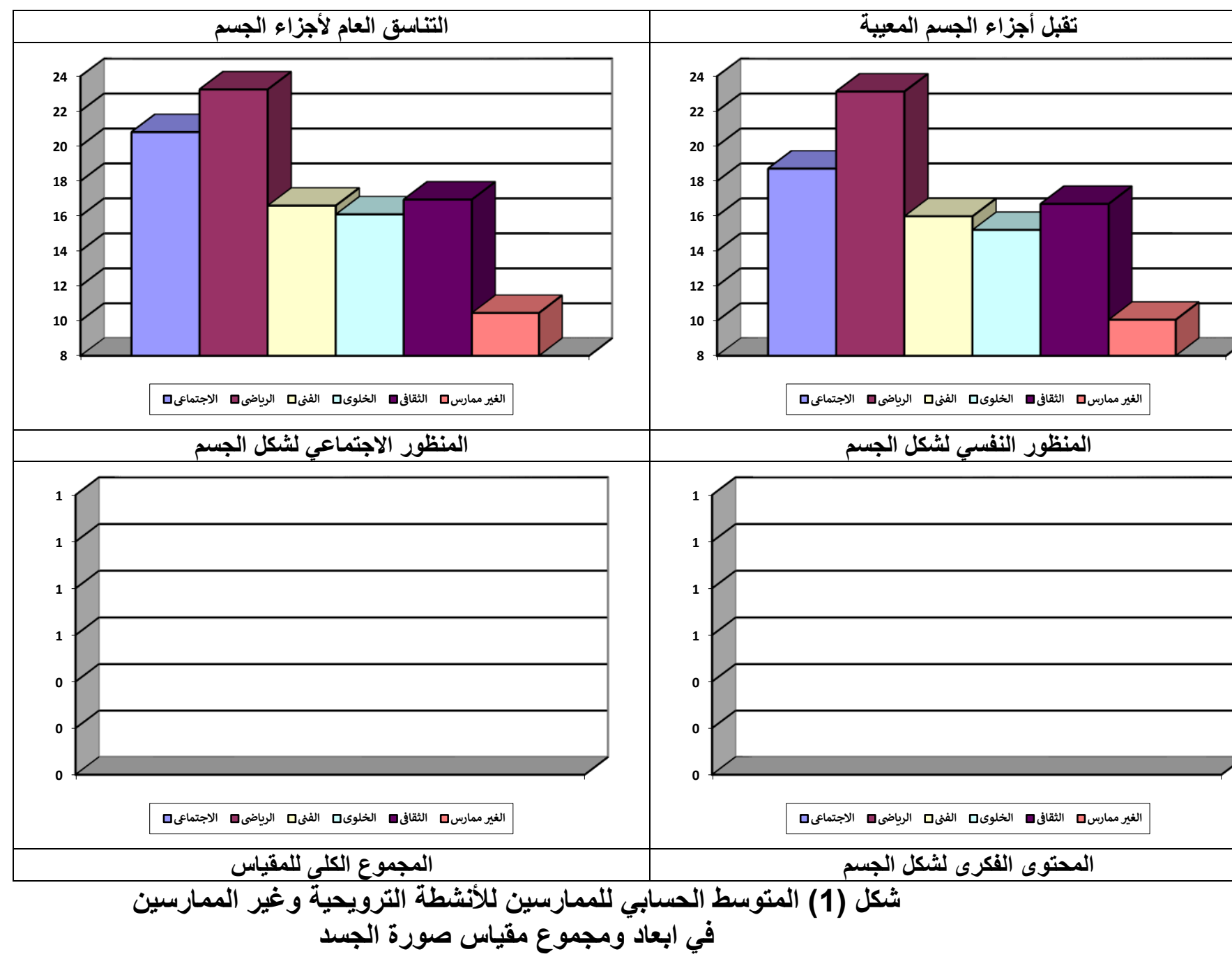

يتضح من جدول (9) و الثكل البيانى رقم ( 1 ) و الخاص بنسبة الفروق \% بين الممارسين و غير الممارسين للأنشطة الترويحية في ابعاد ومجموع مقياس صورة صورة الجسد :

- - بالنسـبة لبعد تقبل أجزاء الجسـم المعيبة نر اوحت نسـبة الفروق بين المجمو عات ما بين

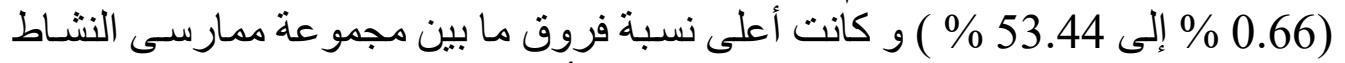

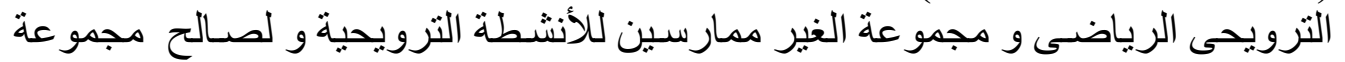
ممارسـى النشـاط الترويحى الرياضسى حيث بلغت نسبة الفروق 53.044 \% بينما كانت

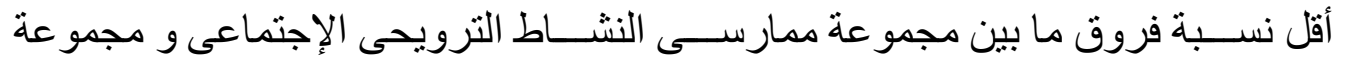




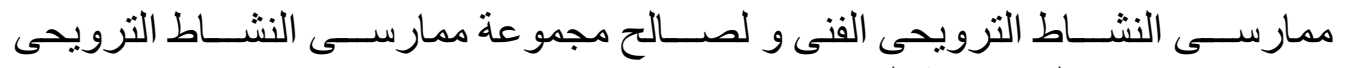
الإجتماعى حيث بلغت نسبة الفروق 0.66 \% .

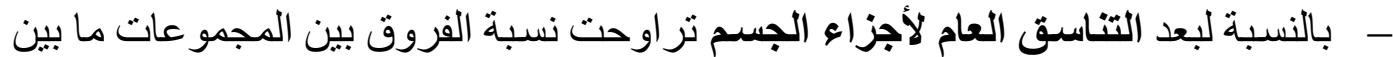

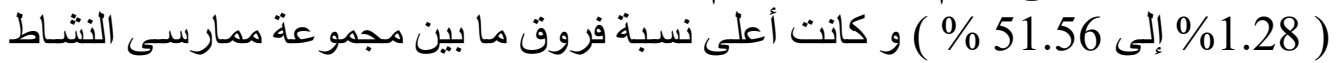

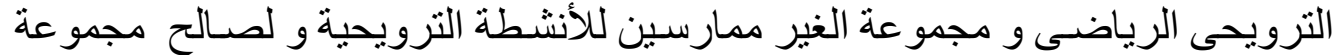

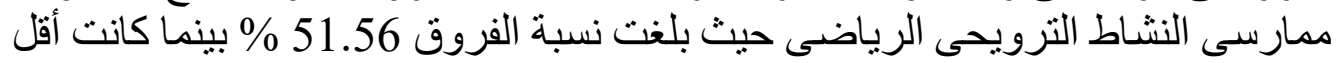

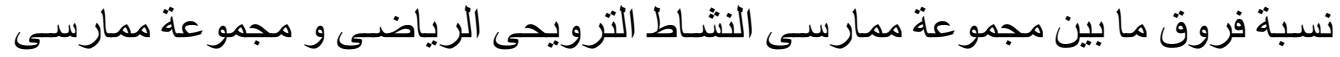

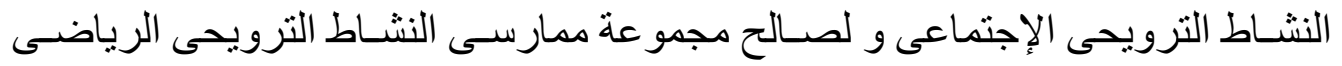
حيث بلغت نسبة الفروق الاجنماعى 1.28 \% .

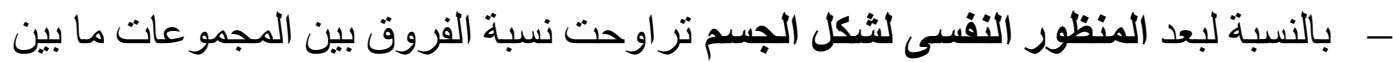

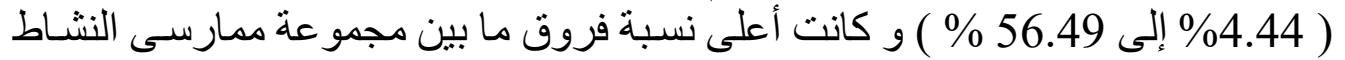

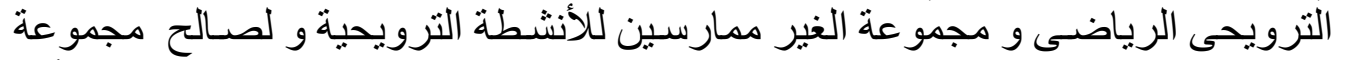
ممارسى النشاط الترويحى الرياضى حيث الثيث بلغت نسبة الفروق 56.49 \% ب بينما كانت أقل

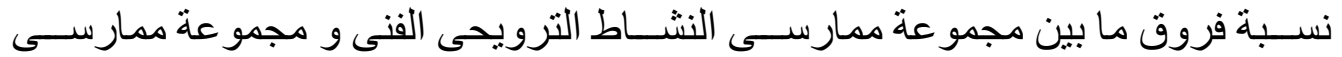

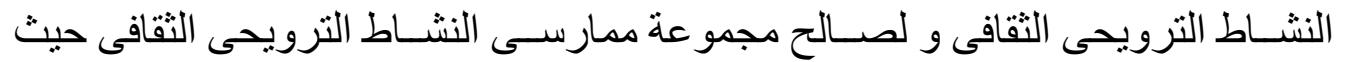
بلغت نسبة الفروق 4.44\% .

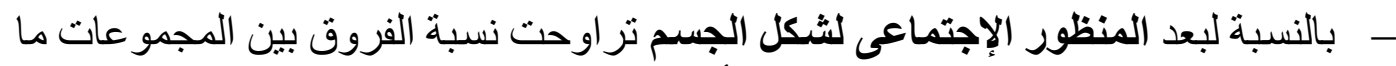

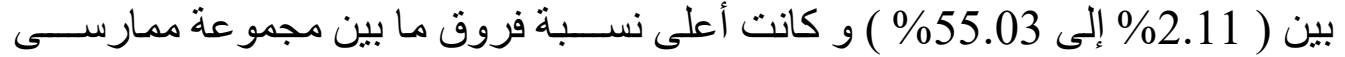

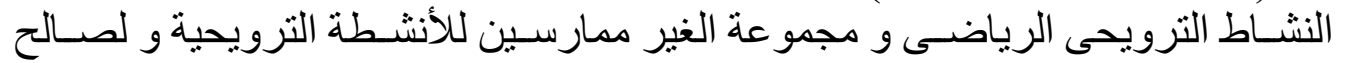

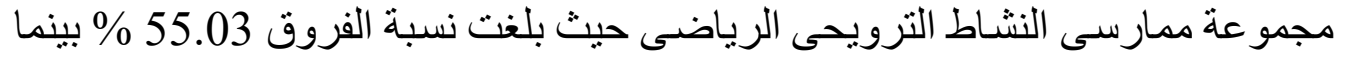

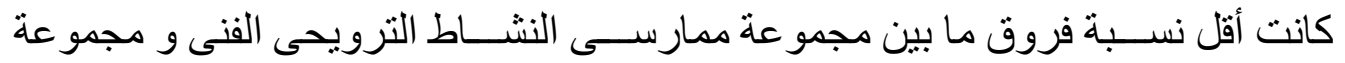

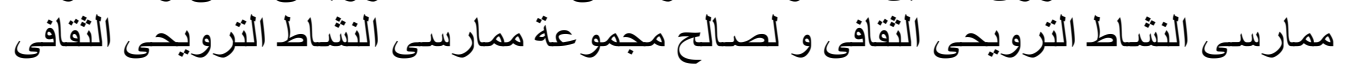
حيث بلغت نسبة الفروق 2.11\% .

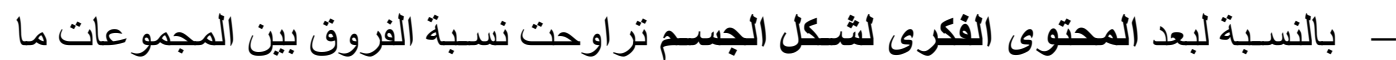

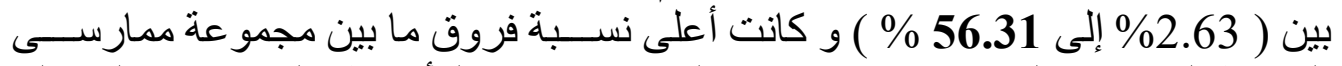

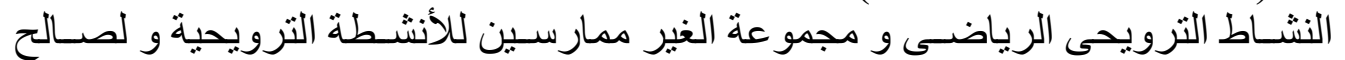

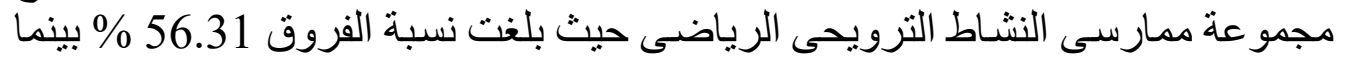

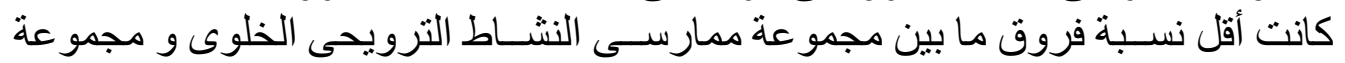

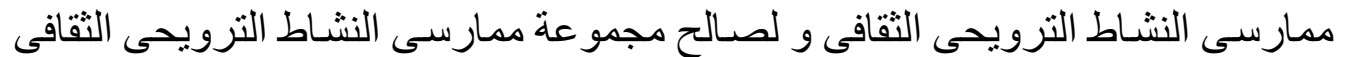
حيث بلغت نسبة الفروق 2.63\% .

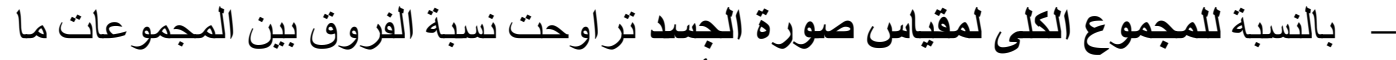

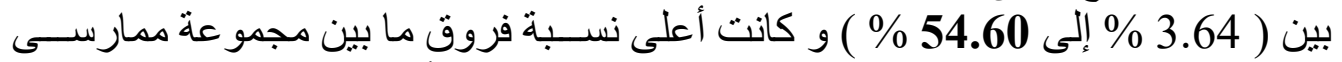

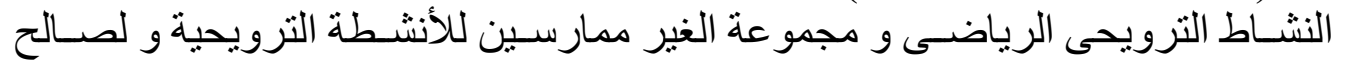

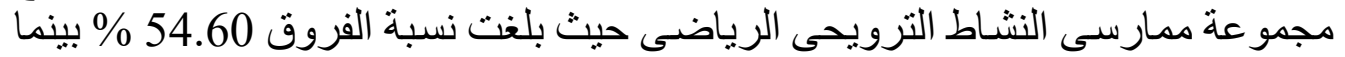

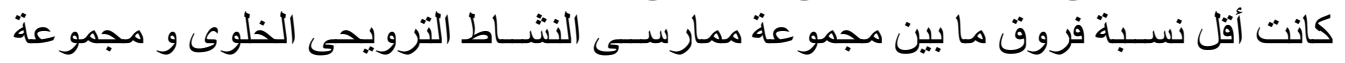

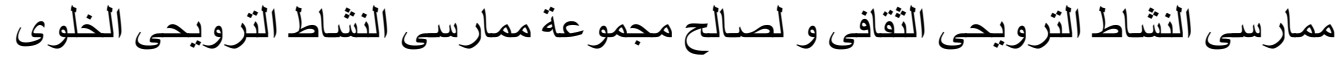
حيث بلغت نسبة الفروق 3.64 \% . 
يتضح من جدول (7) والخاص بتحليل التباين (ANOVA) بين الممارسين وغير

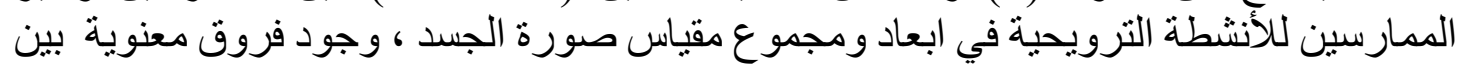

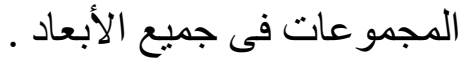

و يتضح من جدول (8) و الخاص بمعنوية الفروق بين الممارسين وغير الممارسين

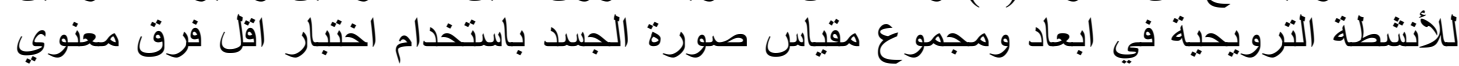

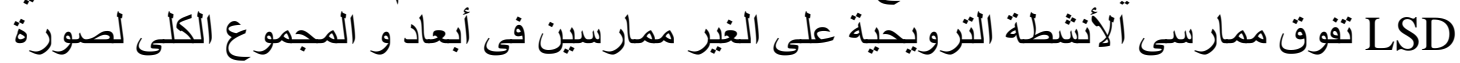

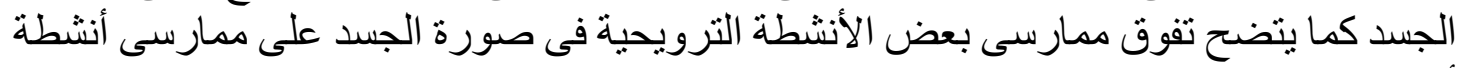

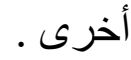

و يتضح من جدول (9) و الثنكل البيانى رقم ( 1 ) و الخاص بنسبة الفروق بين الممارسين

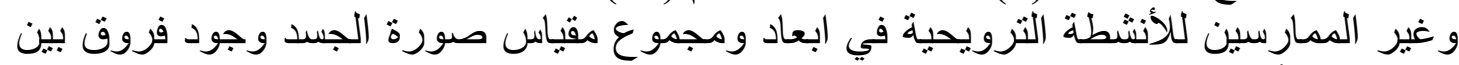

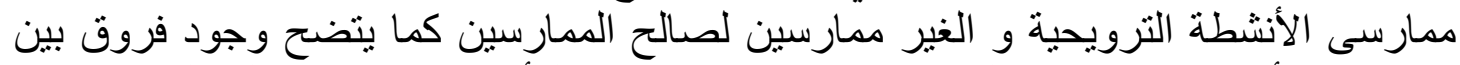

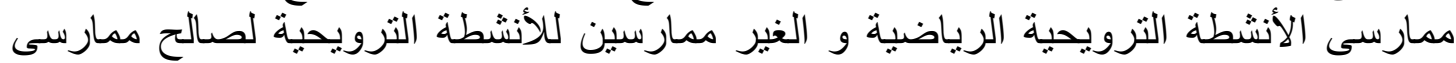
الأنشطة الترويحية الرياضية الأنية الروبية

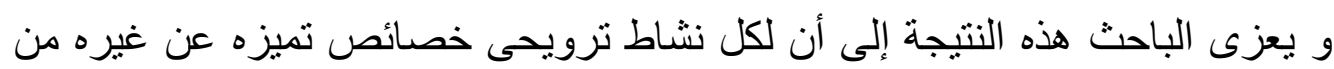

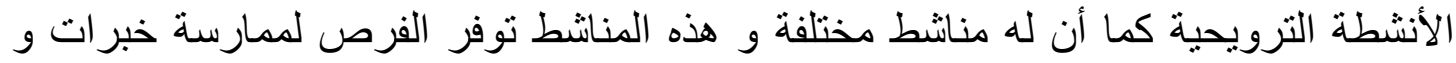

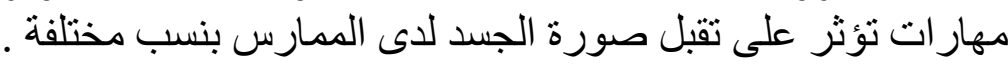

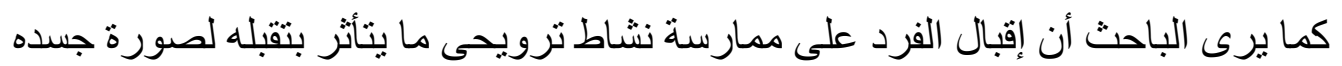

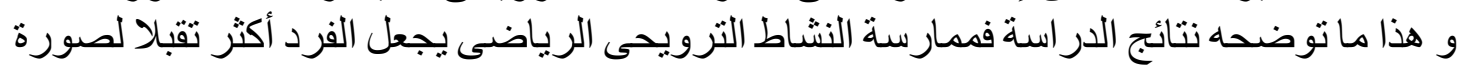

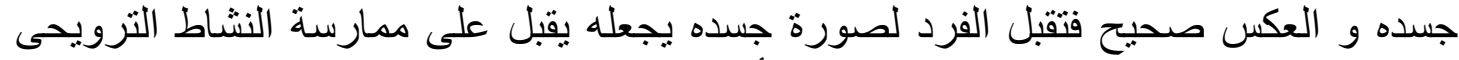

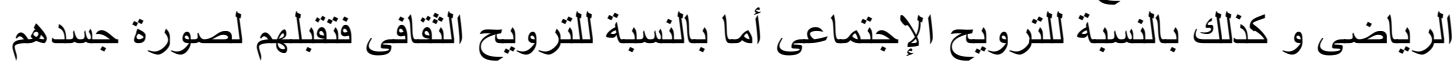

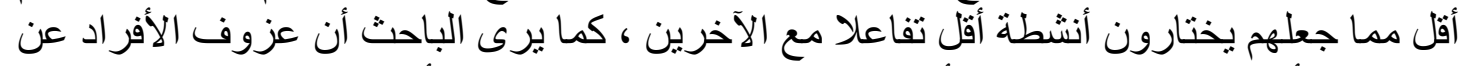

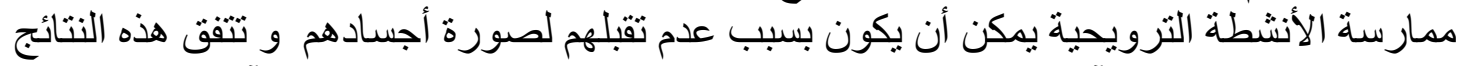

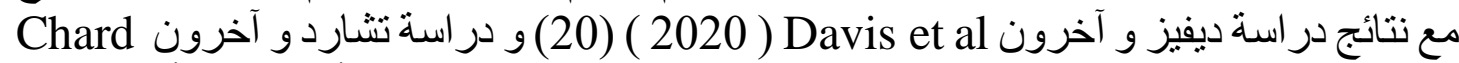

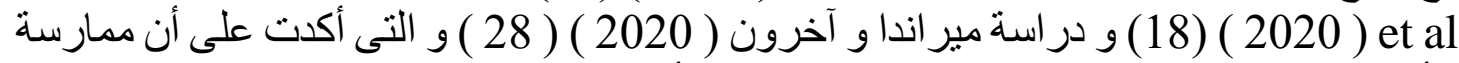
الأنشطة الترويحية تتناسب طرديا مع صورة الجسد أى كلما مارس الفرد نشاط ترويحى زاد اد نقبله

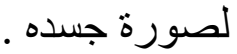
و فى هذا الصدد يشير محمود إسماعيل طلبه (2010) إلى أن الترويح نشاط إختباري بنَّاء

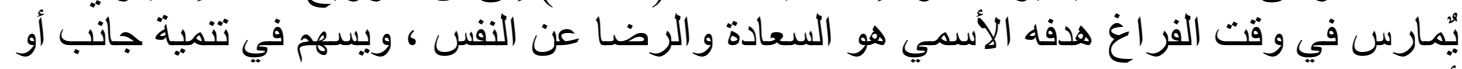

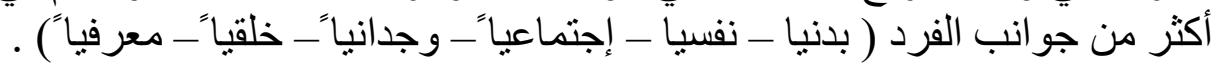
(41: 11$)$

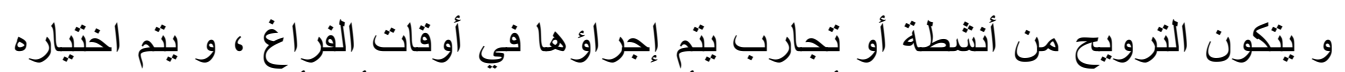

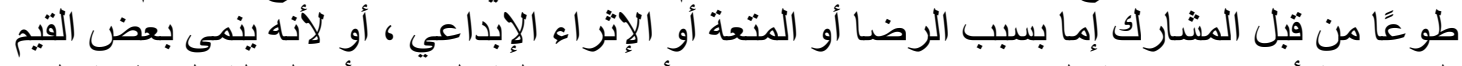

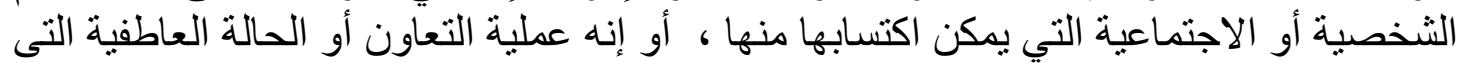
يكتسبها المشارك من المشاركة فى النشاط و التى تعد علاج في بعض النه حالات القلق و الإكتئاب. ( $67: 31$ )

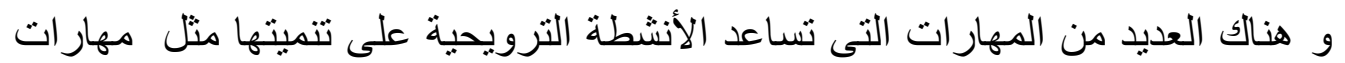
الحباة الجسدية و الفكرية و النفسية الاجتماعية ، و تشمل مهار ات الحيات الحياة الجسدية تلاك المتعلقة باللياقة 
البدنيةو الممارسات الصحية الإيجابية و الأداء الرياضي بينما يمكن أن تشمل مهار ات الحياة الفكرية

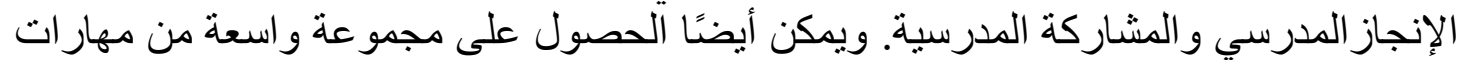

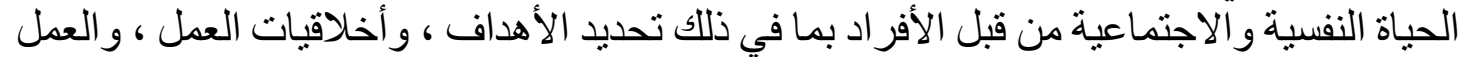

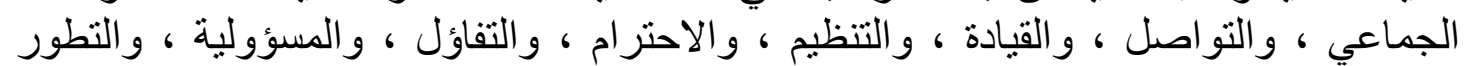
الأخلاقي. ( 22 : 58 )

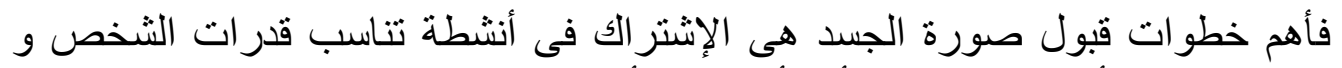

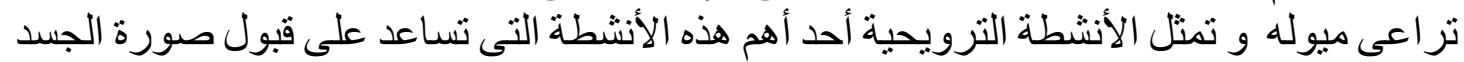
( $873: 15)$.

و الآباء و الأقران ووسائل الإعلام أهم عو امل قبول صورة الجسبد حيث يرتبط شكل الجسم

و الوزن و الدقارنات بعو اطف صورة الجسد الإيجابية والسلبية. ( 13 : 364 )

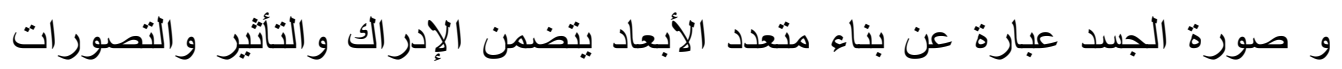

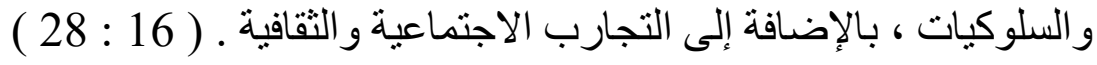

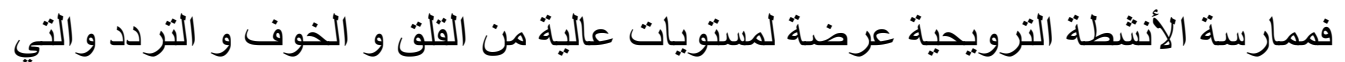

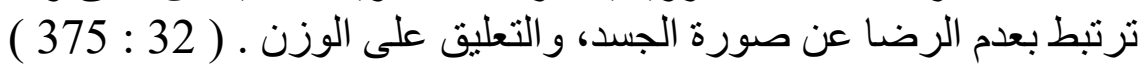

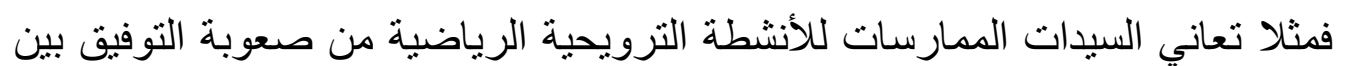

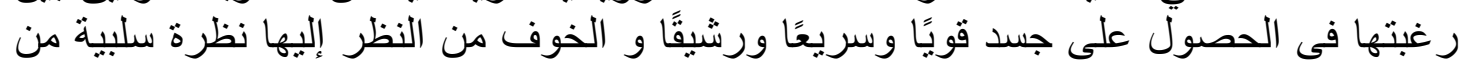

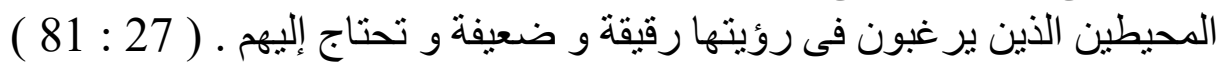

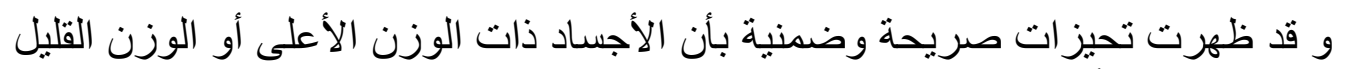

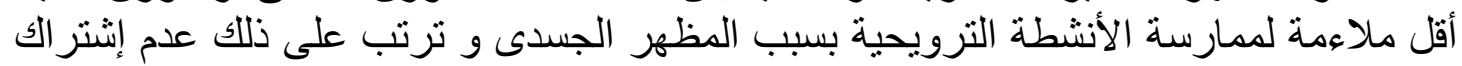

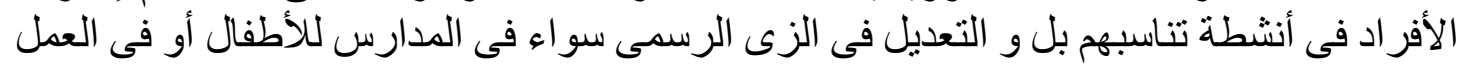

للكبار لمحاولة التسنر على الجسد ـ ( 30 : 941 )

فى ضوء أهداف البحث و النتائج التى تم التوصل اليها استخلص الباحث ما يلى :

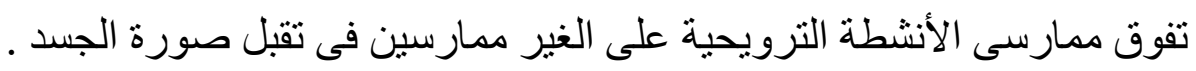

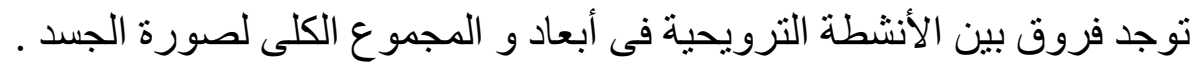

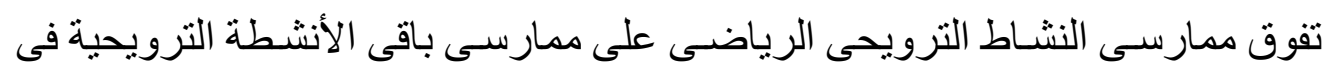


تفوق ممارسى النشاط الترويحى الإجتماعى على ممارسى باقى الأنشطة الترويحية عدا ممارسى النشاط الترويحى الرياضى فى تقبل صورة الإنى على الجسد .

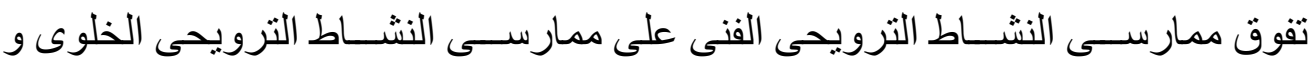

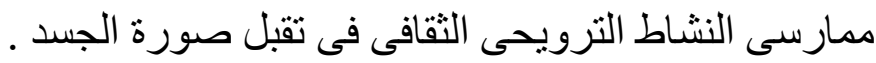

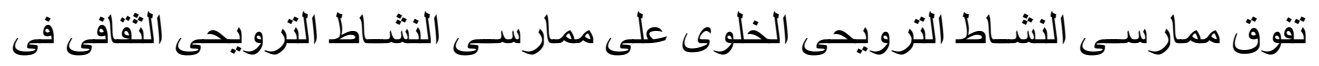
تقبل صورة الجسد.

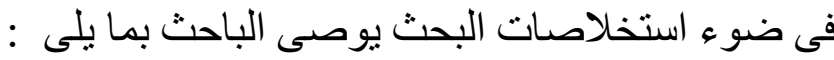

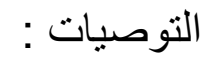

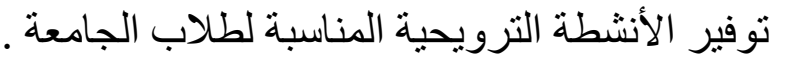

تقالِير صورة الجسد إجتماعيا فصورة الجسـ تعتبر لوحة إعلان خاصـة تزود الآخرين

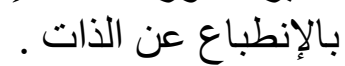
الإشتر الك فى أنشطة تناسب قدرات الثخص و تر اعى ميوله كأهم خطو ات قبول صورة

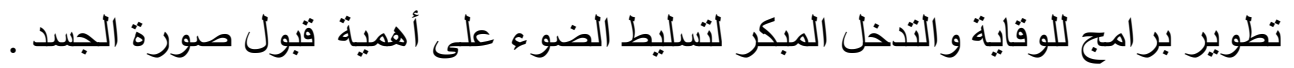

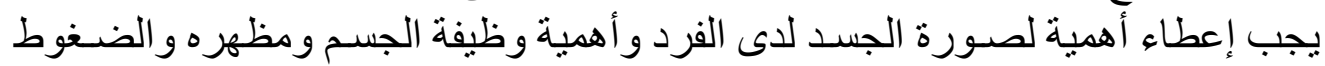

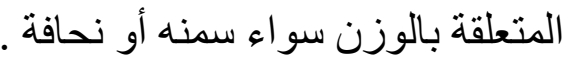

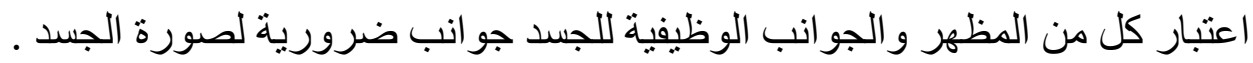

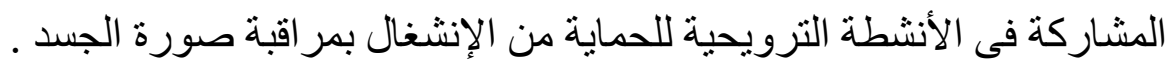

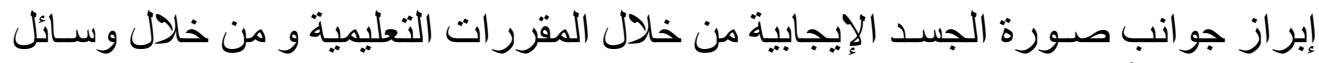

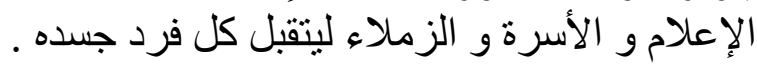

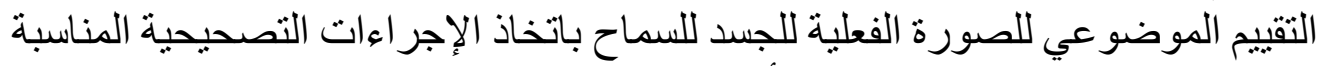

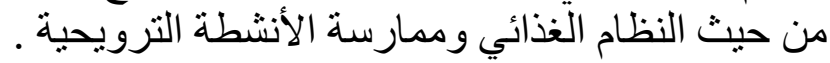

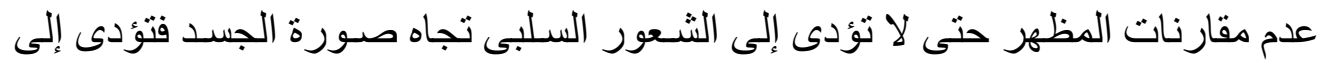

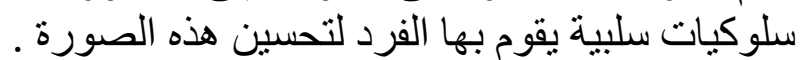

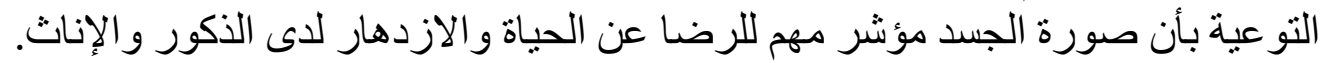

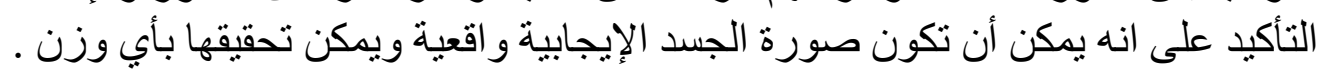

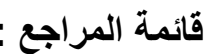

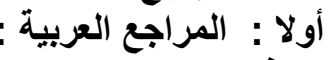

: سلسلة في علم النفس دراسات في السلوك و الثخصبة ، مؤسسة طيبة

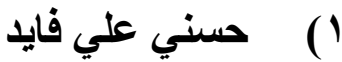

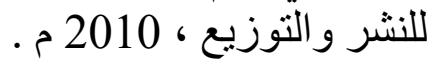

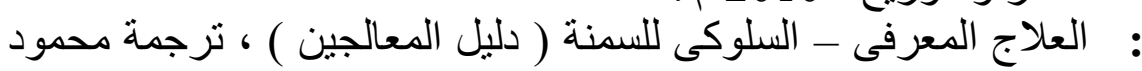

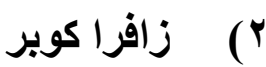

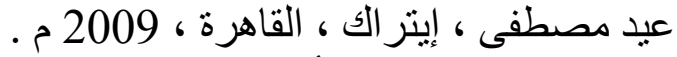

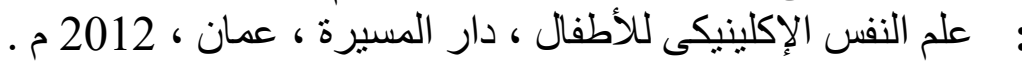

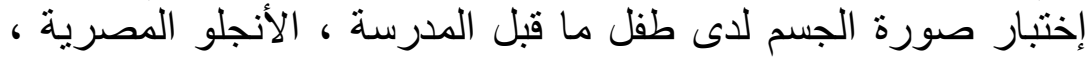
: مبادئ الصحة النفسية ، دار و ائل للطباعة و النشر ، الأردن ، 2011 م. 


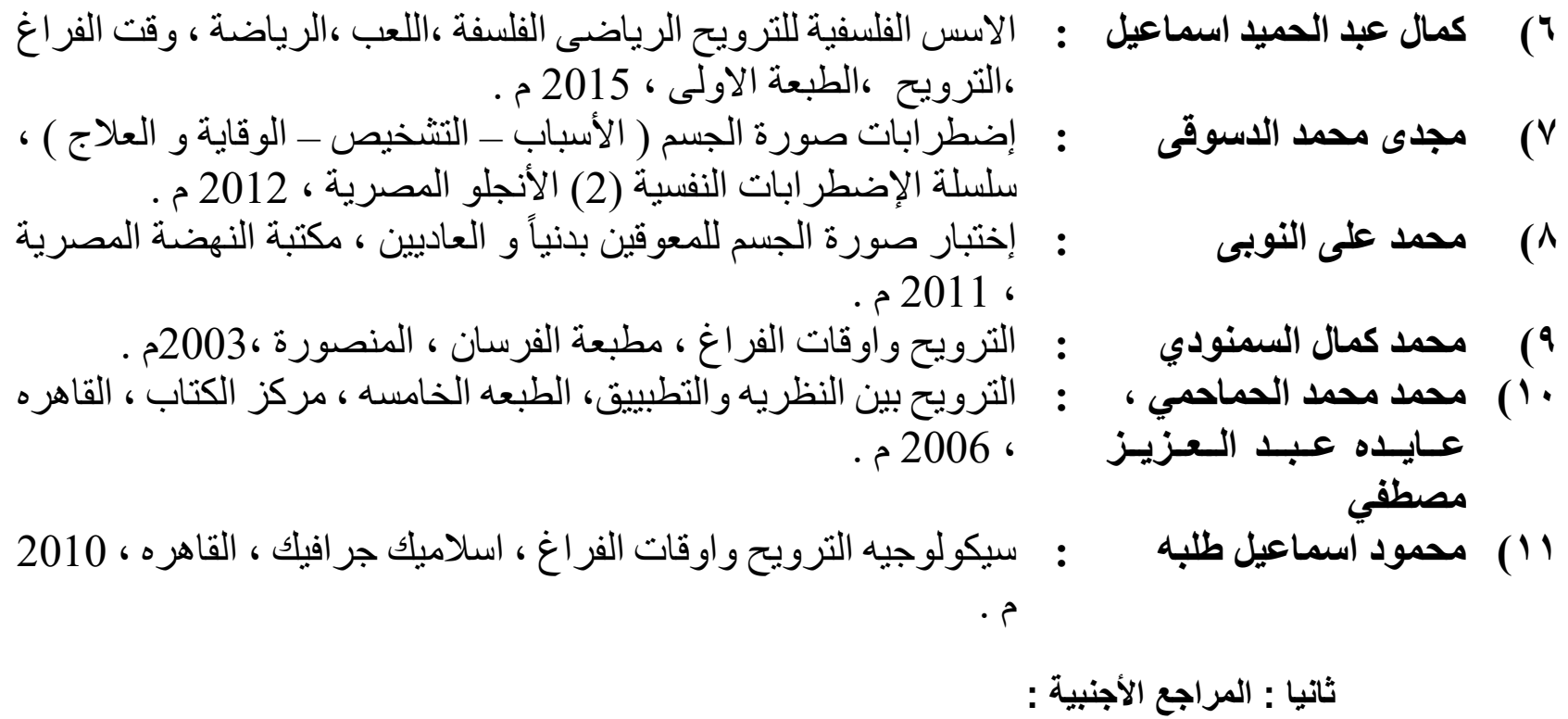

12) Baker \& : Examining the effects of perceptions of community and Palmer recreation participation on quality of life. Social Indicators Research 75 (3): 395-418, 2006.

13) Beckner : RecordNavigating the thin-ideal in an athletic world: Influence of coach communication on female body image and health choices Health Communication, 31 (3) , pp. 364-373,2016.

14) Briand et al : The benefits and economic value of community recreation : Proposal for an analytical framework based on an exploratory study. Canadian Journal of Nonprofit and Social Economy Research, 2(1), 24-44, 2011.

15) Brown et al : A randomized controlled trial of the body project: more than muscles for men with body dissatisfaction. Int $\mathrm{J}$ Eat Disord;50(8):873-83,2017.

16) Cash and : Body image: A handbook of science, practice, and prevention, Smolak (2nd ed.), Guildford Press, New York, 2011.

17) Catalano et al : Prevention science and positive youth development: Competitive or cooperative frameworks? Journal of Adolescent Health, 31, 230-239, 2002.

18) Chard et al : An Inclusive Approach to Exploring Perceptions of Body Image, Self-Esteem, and Physical Activity among Black and African-American Girls: Smart Fit Girls Melanin Magic, Journal of Park and Recreation Administration, [S.1.], ISSN 2160-6862. mar. 2020.

19) Coppola et al : Coaches' communication of sport body image: Experiences of female athletes , Journal of Applied Sport Psychology, pp. 116, 2014.

20) Davis et al : The Role of Body Image in the Prediction of Life Satisfaction and Flourishing in Men and Women. J Happiness Stud 21, 505-524,2020. 
21) Department : Physical education: the National Curriculum for England and for Education Wales (London, DfEE/Qualifications and Curriculum and Authority, 2000.

Employment

22) Gould, D., \& : Life skills development through sport: Current status and future Carson directions. International Review of Sport and Exercise Psychology, 1(1), 58-78, 2008.

23) Grabe et al : The role of the media in body image concerns among women: a meta-analysis of experimental and correlational studies. Psychol Bull,134:460, 2008.

24) Grogan

: Body image: Understanding body dissatisfaction in men, women and children, (3rd ed.), Routledge, New York, 2016

25) Jones et al : An integrative review of sport-based youth development literature. Sport in Society, 20(1), 161-179, 2017.

26) Lee et al

: Body weight misperception and psychological distress among young South Korean adults: the role of physical activity. Glob Heal Res Policy,2:1-10, 2017.

27) Lunde and Gattario

: LPerformance or appearance? Young female sport participants body negotiations , Body Image, pp. 81-89,2017.

28) Miranda et al : Body image disorders associated with lifestyle and body composition of female adolescents, Public Health Nutrition, 111,2020 .

29) Potwarka et : Relationships among producer exposure, producer bias, and al citizenship orientations in the context of public recreation service delivery. Society and Leisure 38 (2): 166- 183, 2015.

30) Puhl, and He : The stigma of obesity: A review and update, Obesity, pp. 941uer

31) Rituparna : The Importance and Impact of Recreational Activities in the Devi Educational Curriculum, the knowledge review, 2018.

32) Slater, M. Tig : Media exposure, extracurricular activities, and appearancegemann related comments as predictors of female adolescents' selfobjectification , Psychology of Women Quarterly, pp.375389, 2015 .

33) Thibault \& : The "leisure city": What are we talking about? World Leisure Lavigne Journal 56 (1): 2- 5, 2014 .

34) Tylka et al : What is and what is not positive body image? Conceptual foundations and construct definition, Body Image, pp. 118129, 2015 .

35) Yager $\mathbf{Z}$, : Body image, nutritional supplement use, and attitudes towards O'Dea J doping in sport among adolescent boys: Implications for prevention programs. JISSN,11:13,2014. 


\section{الملخص}

\section{" ممارسة الانشطة الترويحية و أثرها فى تقبل صورة الجسد "}

تهدف الدر اسة إلى التعرف على تأثير ممارسة الأنشطة الترويحية فى تقبل صورة الجسد ، تم استخدام المنهج الوصفى بالأسلوب المسحى ، و تم إختيار عينة البحث بطريقة عشوائية و بلغت عينة البحث 970 طالب من طلاب الفرق الأربعة بكلية التربية الرياضية بنين جامعة الإسكندرية بنسبة 29 \% من إجمالى طلاب الكلية و البالغ عددهم 3310 طالب و تم التوصل للأنشطة الترويحية الممارسة و توزيع العينة على الأنشطة من خلال البيانات الأساسية للعينة ، و تم استخدام مقياس صورة الجسد كأداة لجمع البيانات ، و توصلت نتائج الدر اسة إلى تفوق ممارسى الأنشطة الترويحية على الغير ممارسين فى تقبل صورة الجسد ، توجد فروق بين الأنشطة الترويحية فى أبعاد و المجموع الكلى لصورة الجسد ، تفوق ممارسى النشاط الترويحى الرياضى على ممارسى باقى الأنشطة الترويحية فى تقبل صورة الجسد ، تفوق ممارسى النشاط الترويحى الإجتماعى على ممارسى باقى الأنشطة الترويحية عدا ممارسى النشاط الترويحى الرياضى فى 


\section{Abstract \\ " Practicing recreational activities and their effect on accepting the body image "}

The study aims to identify the effect of recreational activities on accepting the body image, the descriptive method was used in the survey method, and the research sample was randomly chosen and the research sample reached 970 students from the four teams at the Faculty of Physical Education Boys University of Alexandria by $29 \%$ of the total students The college, whose number is 3310 students, recreational activities practiced and sample distribution to activities were reached through the basic data of the sample, and the body image scale was used as a tool to collect data, and the results of the study reached the superiority of the recreational activities over others practicing in accepting the body image, There are differences between recreational activities in the dimensions and the total body image, the exercise of sports recreational activity is superior to those of the rest of the recreational activities in accepting the body image, social recreational activity practitioners outperform the practitioners of the rest of the recreational activities except for practitioners of sports recreational activity in accepting the body image . 
